\title{
EDGE TRANSITION IMPACTS ON SWAMP PLANT COMMUNITIES IN THE NILGIRI MOUNTAINS, SOUTHERN INDIA
}

\author{
MOHANDASS, D. ${ }^{1}$-PUYRAVAUD, J-P ${ }^{2}$-HUGHES, A. C. ${ }^{3}$ - DAVIDAR, P. ${ }^{4}$ - GANESH, P. S. ${ }^{5}-$ \\ CAMPBELL, M. ${ }^{6}$ \\ ${ }^{1}$ Key laboratory of Tropical Forest Ecology, Xishuangbanna Tropical Botanical Garden \\ $(X T B G)$, Chinese Academy of Sciences, \\ Menglun, Mengla County, Yunnan-666 303, P.R. China \\ ${ }^{2} E C O S$, \\ 9 A Frédéric Ozanam Street, Colas Nagar, Puducherry 605001, India \\ ${ }^{3}$ Centre for Integrative Conservation, Xishuangbanna Tropical Botanical Garden (XTBG), \\ Chinese Academy of Sciences, \\ Menglun, Mengla County, Yunnan- 666303, P.R. China. \\ ${ }^{4}$ Department of Ecology and Environmental Sciences, Pondicherry University, \\ Kalapet, Puducherry -605014, India \\ ${ }^{5}$ Department of Biological Sciences, Birla Institute of Technology \& Science, BITS, \\ Pilani - Hyderabad Campus, India \\ ${ }^{6}$ Centre for Tropical Environmental and Sustainability Science (T.E.S.S), School of Marine and \\ Tropical Biology, James Cook University, \\ Cairns, Queensland, Australia \\ *Corresponding author \\ e-mail:dmohandass@gmail.com \\ (Received $14^{\text {th }}$ Nov 2012; accepted $22^{\text {nd }}$ June 2014)
}

\begin{abstract}
Swamps represent a relatively understudied ecosystem in many regions, which contrasts markedly with the research attention which other wetlands and Mangrove ecosystems have received. In the upper Nilgiris of southern India, montane swamps are restricted to geographic areas with flat surfaces and bounded by different edge transition vegetation types including grasslands and shola forests. Our study examined whether species richness, endemism, edge and the composition of swamp interior communities have a significant relationship with swamp area. Using species-area curves we continued sampling for species in each swamp until species richness reached the asympote within that swamp. Our results suggest that species richness $(\log \mathrm{n}), \log$ endemism, and edge and swamp interior species composition do not increase significantly with increasing area due to edge effect. Moreover, swamp area and vegetation parameters showed no significant relationships. However our results did indicate that swamps species richness and endemism were affected by abiotic and biotic edge effects, particularly physical topographic environment and the structure of adjoining matrix vegetation. Therefore swamp protection and restoration, in addition to the preservation and management of buffer regions may be important conservation criteria to preserve these fragile ecosystems.
\end{abstract}

Keywords: endemism, ecotone, grasslands, Nilgiris, species richness, swamp area, sholas

\section{Introduction}

Habitat loss represents one of the major drivers of regional species loss, and even total species extinction across much of the globe. Therefore developing methods to

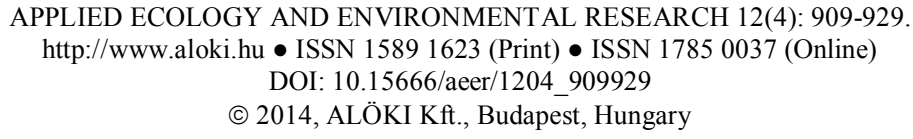


manage and mitigate the impact of habitat destruction on species diversity are major components of conservation strategy (He and Hubbell, 2011). Research is urgently required to develop the best methods to mitigate species loss, through targeted conservation and managing remaining intact habitat regions.

One of the oldest tenets within ecology is that of the species-area relationship (Arrhenius 1921; Gleason 1922; Rosenzweig 1997), whereby the number of species any habitat patch can retain is directly related to the size of that patch. Species-area relationships are also useful predictors to estimate the species richness a patch should be capable of retaining, and thereby a means of calculating the number lost through either habitat loss or other human actions (Rybicki and Hanski, 2013). A further debate is how the shape of the habitat, and the relative proportion of habitat edge (often characterised by denser vegetation and a higher incidence of invasion by alien species) to core habitat effects the ability of that patch to sustain species and how much it impacts (relative to overall area) on the retention of species within habitat fragments (Gonzalez et al., 2010).

Edge effects are also major drivers of change in many fragmented landscapes, but are often highly variable (in terms of structure, and effects) across space and time (Laurance et al. 2007; Murcia 1995; Ries et al. 2004; Laurance et al. 2007). However edge effects can have serious impacts on species diversity and composition, dynamics and ecosystem functioning (Saunders et al. 1991; Chen et al. 1992; Laurance et al. 2007), yet have only been properly considered in a small number of ecosystems.

The total area of a habitat patch/fragment has been found to relate directly to species richness in studies of many ecosystems across the globe (Rosenweig, 1997; Whittaker et al., 2001; William, 1943; Wilcox, 1980; Schoener and Schoener, 1981; Rydin and Borgegard, 1988; Holt et al., 1999; Moody, 2000; Gonzalez et al., 2010). This area to richness relationship exists across extended scales, with mid-domain effects also contributing at larger extents of intact habitat; such as the Amazon basin (Laurance et al. 2007). Interestingly, the number of endemic species is also significantly related with area (Moody, 2000), though this relationship is much more complicated as many endemic species occur in small areas, which are either isolated or have high turnover due to high topographic heterogeniety-and therefore endemism is a much more complex measure than simple species richness. Thus an understanding of floristic patterns and, the species-area relationship of any habitat type (especially rarer habitat types) potentially provides useful insights into the planning of conservation strategies for plant communities within such habitats.

Swamps (wetlands) represent biologically diverse assembelages of species, yet are amongst the most vulnerable ecosystems (Nirmal Kumar and CiniOommen, 2011; Puyravaud et al., 2012; Pitman et al., 2014). In addition to pressures on swamps through drainage and conversion to agriculture, swamps are made more vulnerable by their sparse distribution, as they represent isolated islands, patchy in nature and are dominated by endemic and endangered herbaceous species. This high endemism has been recorded and analysed in a number of regions including in the upper Nilgiris of southern India (Mohandass, 2008; Puyravaud et al., 2012; Mohandass, 2013). Within the Nilgiris region human usage, agricultural conversion and grazing pressures threaten many of the swamps within a formerly highly diverse region and thus these pressures may drive local, or even total extinction of species within the Nilgiris region (Puyravaud et al., 2012). As a consequence of these pressures swamps are becoming increasingly rare and fragile ecosystems throughout the Nilgiri Mountains. 
However, knowledge of swamp plant communities succession and dynamism and community function has received little attention, and therefore determining the impacts of human mediated pressures on biodiversity are difficult to quantify, making prioritisation for conservation difficult or impossible. Because of the lack of baseline information for many regions the use of the relationship between swamp diversity and endemism relative to the area could provide a means of gauging the impacts on habitat loss or alteration on species diversity.

Tropical montane evergreen forest in the upper Nilgiri Mountains (locally termed sholas), are normally stunted and occur in discrete patches, and are confined to sheltered valleys, hollows and depressions, and frequently surrounded by grasslands and swamps. Our former studies investigated that the relationship between species richness and area among 18 shola patches and found a positive relationship between species richness and patch area (Mohandass and Davidar 2010). Many of the swamps within the study area have been affected by various anthropogenic factors including exotic tree plantation, burning, grazing and conversion into agricultural fields. Long-term grazing of swamps within our study area is linked with a higher susceptibility to drought stress in resident plant species (Dong et al., 2011). We build on this knowledge in the present study by exploring natural succession in vegetation surrounding swamp plant communities. This study sets to examine the relationship between swamp species richness and endemism with swamp area, to understand process of succession surrounding the swamp, and ecological response in terms of diversity and endemism to swamp area.

Swamps of the Nilgiri region may be affected in a similar way to those in previous studies which reported that the structure of the adjoining matrix vegetation had a major effect on swamp communities and diversity (Mesquita et al. 1999; Cronin 2003; Pohlman et al. 2007). Thus, this study focused on testing the relationship between total species richness, endemism, edge and swamp interior species richness an assessing the interactions between the swamp edge region with core swamp plant communities.

Therefore, the study examines how swamp species richness and endemism varies at edge transition zones around swamp margins, and estimates relative capacity of swamps to maintain diversity using species-area relationships to understand swamp community dynamics. We explore if there is a relationship between species richness and endemism in both edge and interior regions compared to swamp area, to explore if the swamp buffer region has a significant effect on the capacity of the swamp to maintain species diversity.

\section{Materials and Methods}

\section{Study area}

The study was conducted in the tropical montane swamps of the Korakundah and Upper Bhavani Reserve Forest of the upper Nilgiri Mountains. Reserve Forests represent a category of forest which has lower levels of protection than National Parks (Mohandass and Davidar, 2010). The study sites lie between $11^{\circ} 13^{\prime}$ latitude $\mathrm{N}$ and $76^{\circ}$ $35^{\prime}$ longitudes $\mathrm{E}$ and the elevation ranges between 2100-2400 $\mathrm{m}$ above mean sea level (Fig. 1). The mean annual rainfall recorded at Upper Bhavani Electricity department and Korakundah tea estate, during the periods for ten years (1993-2006) was 2637mm and $1887 \mathrm{~mm}$ respectively. The distance between these two sites was approximately 8 - 
$13 \mathrm{kms}$. The climate and geological information for the region has been published in previous studies (Mohandass, 2008; Puyravaud et al., 2012).

Swamps in the study area are generally flat-tables in depressions between slopes and grasslands and are normally small and isolated from one another, although large extensive swamps do occasionally occur. Swamps are a reflection of local topography coupled with drainage and local climate, and therefore can only occur in specific, limited regions. Slope gradient and topographic structure determines swamp location, through influencing soil nutrients and enhancing water holding capacity, and therefore swamp plant communities are non-randomly distributed. As a consequence, swamp ecotones may be more sensitive to disturbance and colonization especially of grassland species, as any changes which alter the retention of moisture or cause the drainage properties to change (Kent et al., 1997), are likely to facilitate the transition of the swamp to other types of habitat.

Flowering of most swamp species occurs during the monsoon period (June to November). Swamp communities are largely dominated by grasses and forbs, however some woody species also occur and generally flower from January to May (Mohandass pers. obs.). Most of the swamps in the study region were dominated by exotic tree plantations, of Australian black wattle and various Eucalyptus species (introduced in the 1950s) and pine trees which were planted from the 1960s onwards. Many swamps have already been converted into grasslands, grazing land and agricultural areas and belong to private owners or local government bodies. Local government agencies generally consider swamps as wastelands and there is generally a lack of awareness of both the floristic diversity of swamps and their ecological value.

\section{Methods of data collection}

A floristic survey was carried out from September 2001 to February 2002, and August 2002 to October 2002 in thirteen swamps throughout the Korakundah and Upper Bhavani regions (Fig. 1) (surrounding vegetation types including exotic tree species such as Acacia dealbata Link. Eucalyptus globules Labill, and Pinus patula Schiede ex Schltdl. \& Cham., within plantations, in addition to native sholas and grasslands. All the studied swamps were marked by GPS points and topographical maps were made (Fig. 1; Table 1).

Various anthropogenic activities including grazing, exotic tree plantation and fire have occurred in all swamp regions included within the study (Puyravaud et al., 2012). For all thirteen swamps, sampling effort success and effectiveness was quantified through construction of cumulative species-area curve for each individual swamp starting from the first sample unit $\left(0.5 \mathrm{~m}^{2}\right)$ to the largest swamp present within the study region $\left(1024 \mathrm{~m}^{2}\right)$ (Fig. 2). For five swamps included within this analysis, abundance and ground cover of plant species had previously been recorded and published (Mohandass, 2008; Puyravaud et al., 2012). In all thirteen swamps sampling effort was terminated once the species-area curve reached its asymptote. All plants were identified to species using various regional published floras (Bor, 1960; Fyson, 1932; Gamble, 1967; Matthew, 1999). The botanical revised names were followed according to APG III plant classification (Bremer et al. 2009). Species identification was confirmed by consulting herbaria collections at the Botanical Survey of India, Coimbatore, and Survey of Medicinal Plants and Collection Unit, Ootacamund. Rare, Endangered and Threatened (RET) and Endemic species were categorized according to the Flora of endemic plants (Nair and Henry, 1983; Ahemdullah and Nayar, 1986). A voucher 
specimen of each species was deposited at the Department of Ecology and Environmental Sciences, Pondicherry University, India.

Table 1. showed site code, swamp names, geographical location, , altitude (m), swamp size (ha), sampling unit of each site, number of species, number of edge species, number of swamp interior species, number of endemics, and surrounding vegetation types status of the 13 surveyed swamps in the upper Nilgiris Mountains, India.

\begin{tabular}{|c|c|c|c|c|c|c|c|c|c|c|}
\hline Site code & $\begin{array}{l}\text { Geographical } \\
\text { coordinates } \\
\end{array}$ & $\begin{array}{c}\text { Altitude } \\
\text { (m) }\end{array}$ & Shapes & Size (ha) & $\begin{array}{l}\text { Sampled } \\
\text { area }\left(\mathrm{m}^{2}\right)\end{array}$ & $\begin{array}{l}\text { Species } \\
\text { richness }\end{array}$ & $\begin{array}{c}\text { Number of } \\
\text { edge } \\
\text { species } \\
\end{array}$ & $\begin{array}{c}\text { Number of } \\
\text { swamp } \\
\text { interior } \\
\text { species } \\
\end{array}$ & $\begin{array}{c}\text { Number of } \\
\text { endemic } \\
\text { species } \\
\end{array}$ & $\begin{array}{c}\text { Surrounding } \\
\text { vegetation types }\end{array}$ \\
\hline GD & $\begin{array}{l}11^{\circ} 14.367^{\prime} \mathrm{N} \\
76^{\circ} 35.657^{\prime} \mathrm{E}\end{array}$ & 2236 & $\begin{array}{l}\text { Rectangle } \\
\text { /triangle }\end{array}$ & 0.8 & 64 & 50 & 18 & 32 & 10 & \\
\hline KT & $\begin{array}{l}11^{\circ} 12.387^{\prime} \mathrm{N} \\
76^{\circ} 34.158^{\prime} \mathrm{E}\end{array}$ & 2224 & $\begin{array}{l}\text { Rectangle } \\
\text { /triangle }\end{array}$ & 4,2 & 128 & 51 & 19 & 32 & 7 & $\begin{array}{l}\text { Grassland \& } \\
\text { shola forest }\end{array}$ \\
\hline $\mathrm{KG}$ & $\begin{array}{l}11^{\circ} 12.879^{\prime} \mathrm{N} \\
76^{\circ} 33.352^{\prime} \mathrm{E}\end{array}$ & 2270 & oval/round & 4 & 256 & 47 & 17 & 29 & 9 & $\begin{array}{l}\text { Grassland \& } \\
\text { Plantation }\end{array}$ \\
\hline KK & $\begin{array}{l}11^{\circ} 12.992^{\prime} \mathrm{N} \\
76^{\circ} 33.638^{\prime} \mathrm{E} \\
11^{\circ} 14.978^{\prime} \mathrm{N}\end{array}$ & 2251 & oval/round & 2 & 512 & 53 & 16 & 36 & 9 & $\begin{array}{l}\text { Grassland \& } \\
\text { Plantation }\end{array}$ \\
\hline $\mathrm{KV}$ & $76^{\circ} 35.200^{\prime} \mathrm{E}$ & 2279 & oval/round & 6 & 256 & 52 & 18 & 31 & 8 & shola forest \\
\hline NT & $\begin{array}{l}11^{\circ} 12.069^{\prime} \mathrm{N} \\
76^{\circ} 33.628^{\prime} \mathrm{E}\end{array}$ & 2254 & $\begin{array}{l}\text { Rectangle } \\
\text { /triangle }\end{array}$ & 0.7 & 256 & 50 & 14 & 33 & 8 & $\begin{array}{c}\text { Grassland \& } \\
\text { Plantation }\end{array}$ \\
\hline $\mathrm{NU}$ & $\begin{array}{l}11^{\circ} 13.082^{\prime} \mathrm{N} \\
76^{\circ} 32.989^{\prime} \mathrm{E}\end{array}$ & 2289 & oval/round & 1.2 & 128 & 53 & 15 & 36 & 10 & Grass land \\
\hline OT & $\begin{array}{l}11^{\circ} 13.889^{\prime} \mathrm{N} \\
76^{\circ} 36.173^{\prime} \mathrm{E}\end{array}$ & 2218 & $\begin{array}{l}\text { Rectangle } \\
\text { /triangle }\end{array}$ & 2.8 & 512 & 63 & 12 & 51 & 12 & $\begin{array}{l}\text { Grassland \& } \\
\text { Shola forest }\end{array}$ \\
\hline PT1 & $\begin{array}{l}11^{\circ} 12.580^{\prime} \mathrm{N} \\
76^{\circ} 34.523^{\prime} \mathrm{E}\end{array}$ & 2209 & $\begin{array}{l}\text { oval } \\
\text { /round }\end{array}$ & 1.5 & 128 & 57 & 10 & 43 & 8 & $\begin{array}{l}\text { Grassland \& } \\
\text { Shola forest }\end{array}$ \\
\hline PT2 & $\begin{array}{l}11^{\circ} 12.542^{\prime} \mathrm{N} \\
76^{\circ} 34.527^{\prime} \mathrm{E}\end{array}$ & 2206 & $\begin{array}{l}\text { Rectangle } \\
\text { /triangle }\end{array}$ & 1 & 256 & 56 & 19 & 34 & 9 & $\begin{array}{l}\text { Grassland \& } \\
\text { Shola forest }\end{array}$ \\
\hline $\mathrm{PC}$ & $\begin{array}{l}11^{\circ} 14.632^{\prime} \mathrm{N} \\
76^{\circ} 35.488^{\prime} \mathrm{E}\end{array}$ & 2258 & $\begin{array}{l}\text { Rectangle } \\
/ \text { triangle }\end{array}$ & 0.9 & 128 & 51 & 17 & 31 & 10 & Grass land \\
\hline QT & $\begin{array}{l}11^{\circ} 12.898^{\prime} \mathrm{N} \\
76^{\circ} 34.482^{\prime} \mathrm{E}\end{array}$ & 2215 & $\begin{array}{l}\text { Oval } \\
\text { /round }\end{array}$ & 3.3 & 128 & 66 & 19 & 45 & 10 & $\begin{array}{c}\text { Grassland \& } \\
\text { Plantation }\end{array}$ \\
\hline $\mathrm{TE}$ & $\begin{array}{l}11^{\circ} 13.186^{\prime} \mathrm{N} \\
76^{\circ} 32.581^{\prime} \mathrm{E}\end{array}$ & 2259 & $\begin{array}{l}\text { Rectangle } \\
\text { /triangle }\end{array}$ & 1.8 & 256 & 46 & 16 & 29 & 7 & $\begin{array}{l}\text { Grassland \& } \\
\text { Plantation }\end{array}$ \\
\hline
\end{tabular}

All swamps species were pooled for estimation of species richness. The area of each swamp was determined using data provided by the Tamilnadu Forest Department. RET/species were categorized as per the Flora of endemic plants (Ahmedullah and Nayar, 1986; Nair and Henry, 1983). Edge zone species were considered as the species found within 5-10 metres $(\mathrm{m})$ of swamp edges. Species found at a distance of $\geq 10 \mathrm{~m}$ from the edges were considered as swamp interior species (Fig. 2). Life form was recorded through morphological and vegetative characters with field observation made during 2001 to 2002. Plant group was categorized according to plant classification of angiosperms viz., dicots and monocots. Life form was classified as: annual forbs, perennial forbs, perennial grass, annual grass and perennial woody stems (Rogers and Hartnett, 2001). 


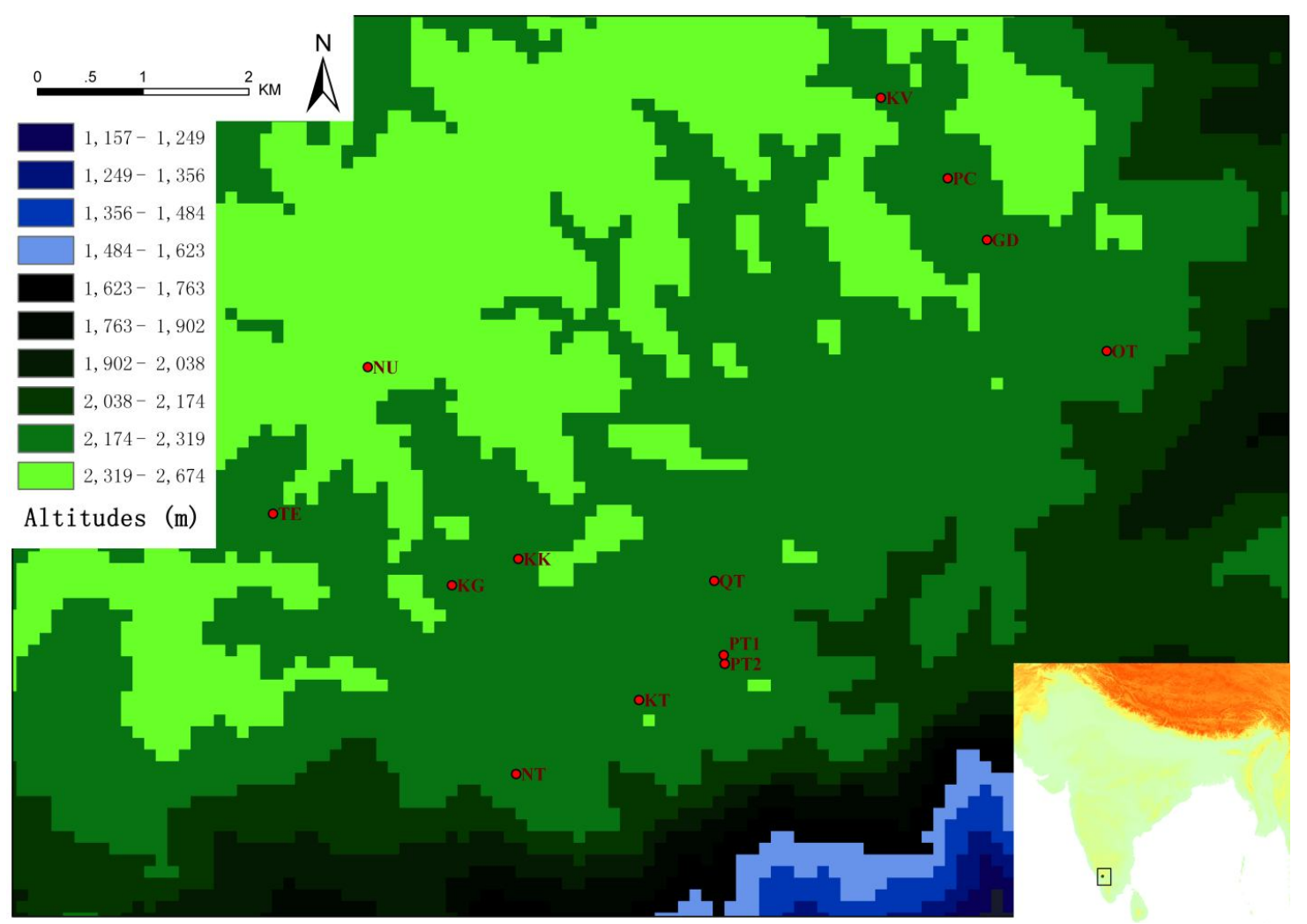

Figure. 1. Location of the surveyed thirteen swamps with site code of the upper montane rainforest of the Nilgiris, Western Ghats, India.

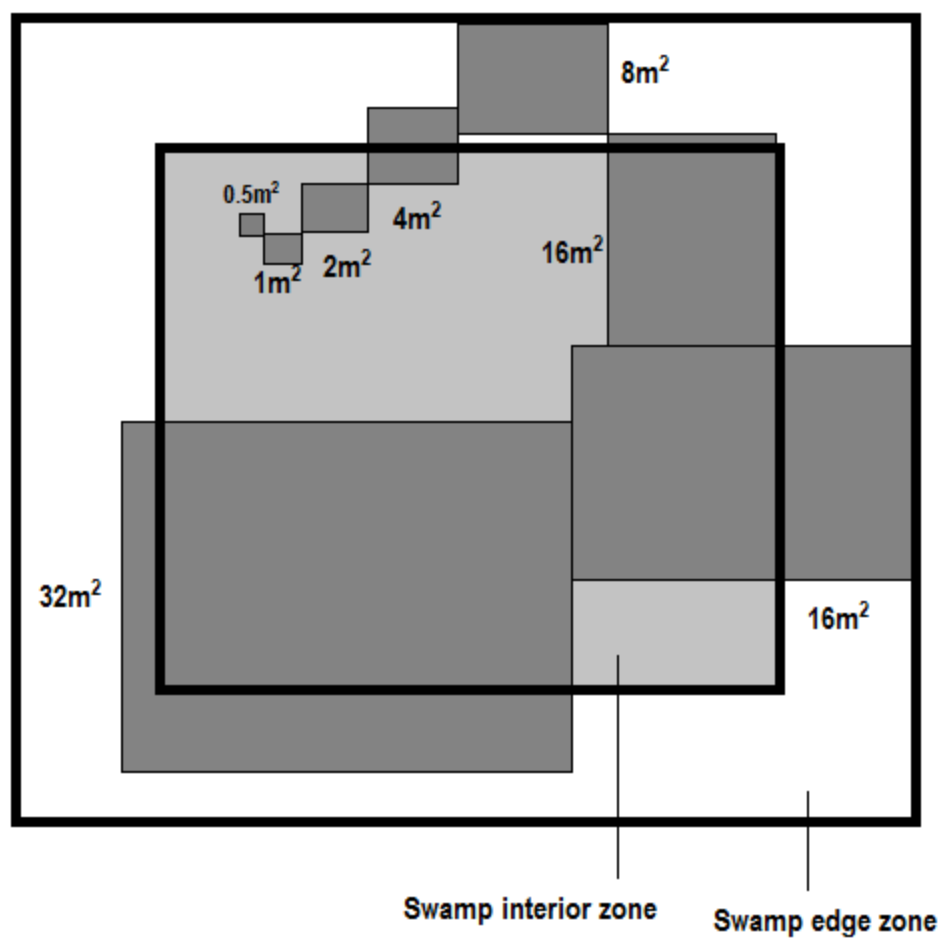

Figure 2. Sampling quadrat pattern in each swamp that have made sampling effort to cover edge zone and swamp interior zones of the Nilgiri mountains. 


\section{Floristic analyses}

A Chi-square test was used to determine the variation of species richness among different vegetation variables. The species richness, endemism and area size was log transformed for analysis. The relationship between swamp area and vegetation parameters were analyzed using linear regression and ANOVA. Pearson correlation coefficient was used for analysis between swamp size (ha) and vegetation parameters. Differences between life forms were tested using one way ANOVA. Significant association was tested between life and plant group by likelihood ratio chi-square (Gtest) of two-way contingency tables. All statistical tests were conducted using SPSS Inc (2000) and Past version 2.12 (Hammer et al., 2001).

\section{Species area curves}

In all the sampled swamps, the cumulative number of species was terminated when it reached a plateau or asymptote. In twelve of the swamps, the cumulative number of species was terminated at the area unit of $512 \mathrm{~m} 2$ however a large swamp reached a plateau at $1024 \mathrm{~m} 2$ (Fig. 3).

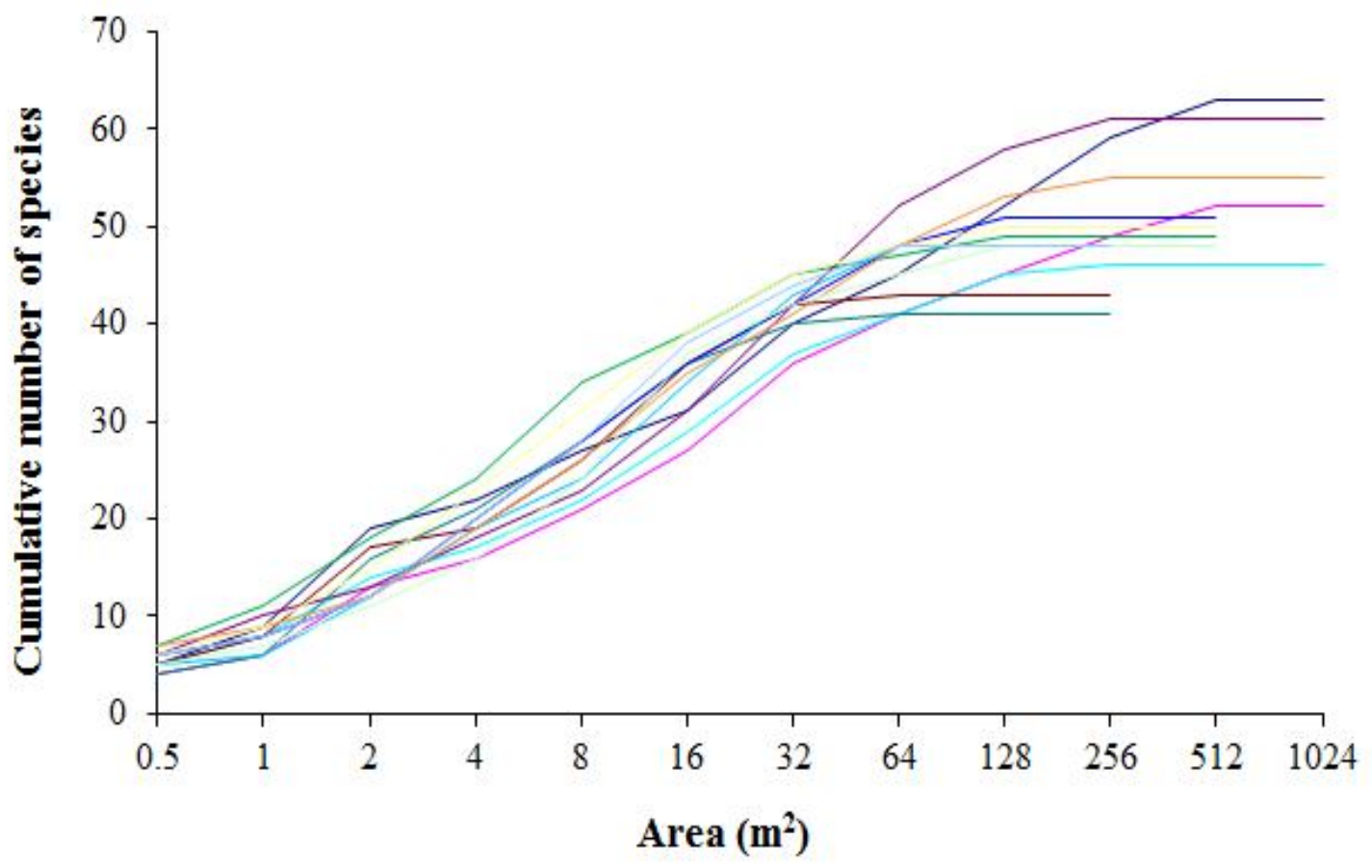

Figure 3. It exhibits sampling effort made showing cumulative number of species increases and reaches a plateau at $512 \mathrm{~m} 2$ in twelve swamps and a large swamp reached a plateau at 1024 $m 2$ in thirteen swamps of the upper Nilgiri Mountains, India.

\section{Results}

A total of 84 species belonging to 67 genera and 33 families were recorded in the thirteen swamps (Appendix 1). The average species richness of each swamp was 53.4 (Std. Deviation $S D=5.8$, range 46-66) (Table 1). Overall annual forbs represented 39\%

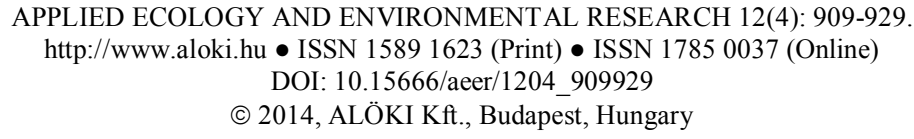


of species found, followed by perennial grass $(31 \%)$, perennial forbs $(23 \%)$, perennial woody stems (5\%) and annual grasses (2\%) (Fig. 4). The frequency of life-form was not significantly different among different swamps $(\mathrm{F}=0.07 \mathrm{df}=44, \mathrm{~ns})$. However, there is a significant association between life form (such as grasses, forbs, and woody plants) and plant group (i.e dicot and monocot) (G-test $=60.81, \mathrm{df}=4, \mathrm{P}=0.0001$ ) (Appendix $1)$.

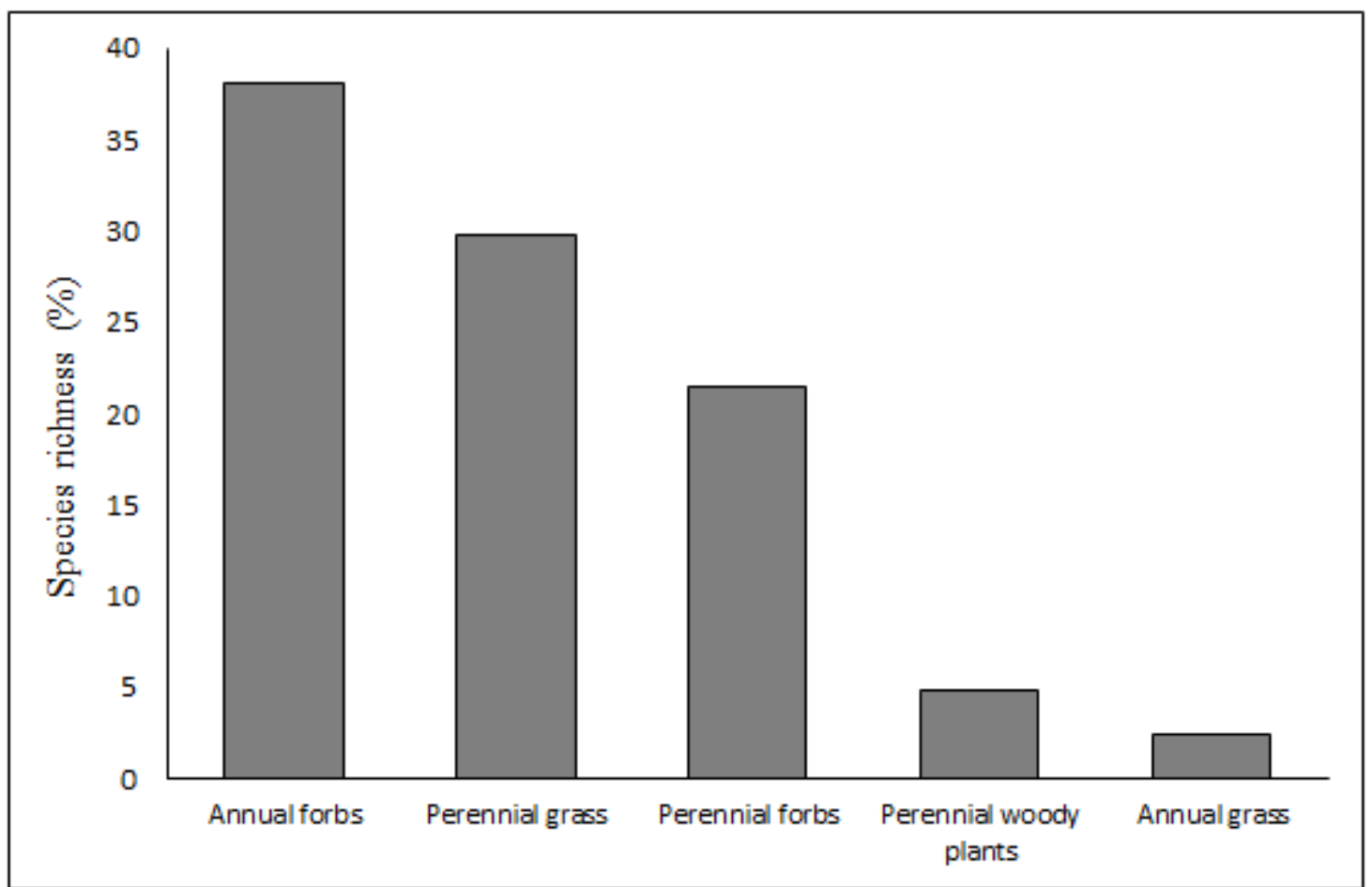

Figure 4. Percentage frequency of swamp life-form species among thirteen swamps in the upper Nilgiri Mountains

Of these, $17 \%$ of species recorded were RET/endemic to Nilgiri/Palni hills and Western Ghats, with a mean value of $8.84(S D=1.1)$ and shared species ranging from 7-10 (approximately $15 \%$ of total species encountered). Additionally, the average edge species richness was $16.2(S D=2.8)$ and the average swamp interior species was 35.5 $(S D=6.7)$ for each swamp studied.

The frequency of endemism was not significantly varied from total species richness $\left(\chi^{2}=1.57, \mathrm{df}=12, \mathrm{~ns}\right)$, thus showed endemism was relatively higher among all swamps. Besides, the frequency of edge species richness was not significantly varied from total species richness $\left(\chi^{2}=7.12, \mathrm{df}=12, \mathrm{P}=0.85\right)$, thus indicates edge species richness was relatively high.

The $\log$ species $(\log n$ species richness) did not significantly increase with swamp area $\left(\mathrm{R}^{2}=0.052, \mathrm{n}=13 ; \mathrm{P}=0.45\right.$; Fig. 5 a ANOVA $\mathrm{F}_{12,13}=0.60$, ns $)$. When analyzed separately edge and swamp interior species were found not to increase significantly with swamp area $\left(\mathrm{R}^{2}=0.00, \mathrm{~ns}\right.$, and $\left.\mathrm{R}^{2}=0.04, \mathrm{~ns}\right)$, respectively. Similarly log endemism did not increase with swamp area $\left(\mathrm{R}^{2}=0.072, \mathrm{n}=13 ; \mathrm{P}=0.38\right.$, Fig. $5 b$; ANOVA $\mathrm{F}_{13,12}=$ 
2.73, ns). This shows that regionally, swamps plant communities are impacts on edge effect caused by the structure of the adjoining matrix vegetation such as grasslands and sholas with the influence of topographic structure.

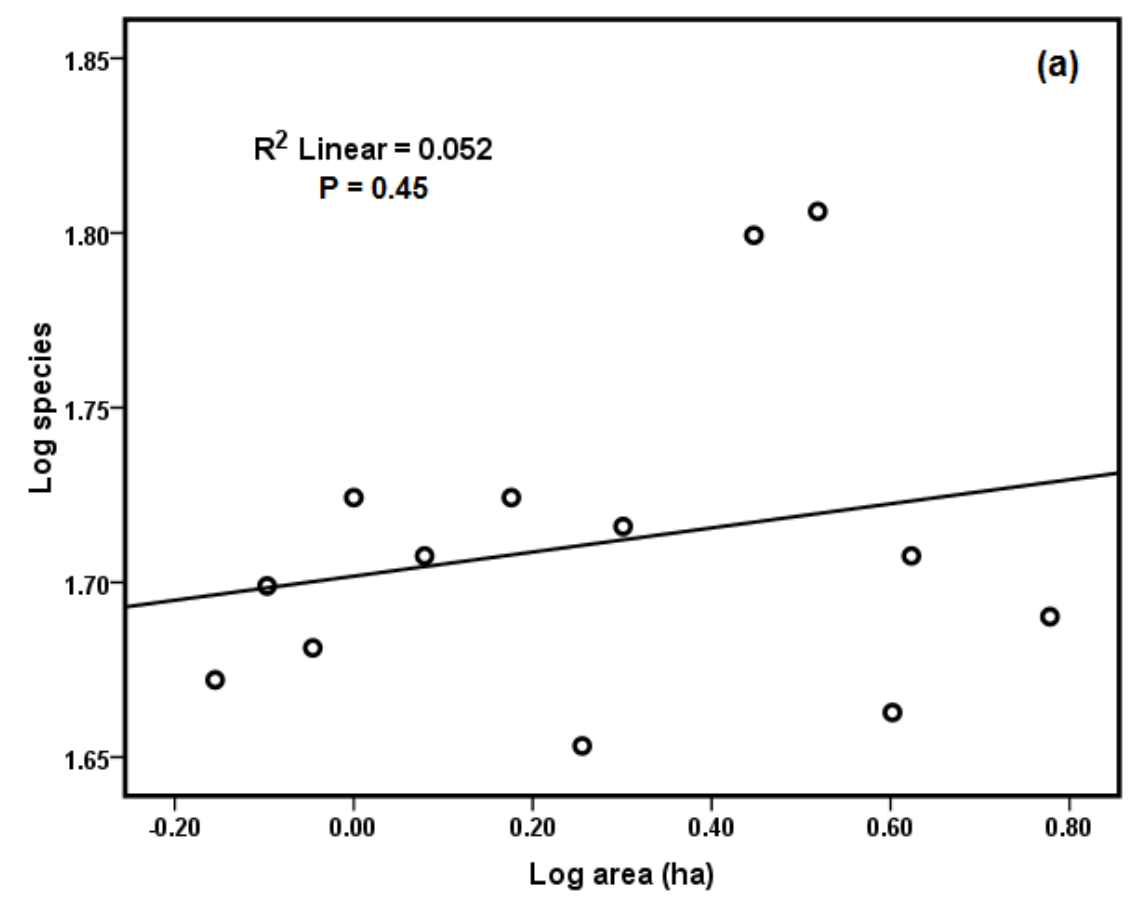

Figure 5a. The log species and (log) and swamp log area (ha) $(R 2=0.05 \mathrm{~N}=13$, n.s) with each point representing an individual swamp

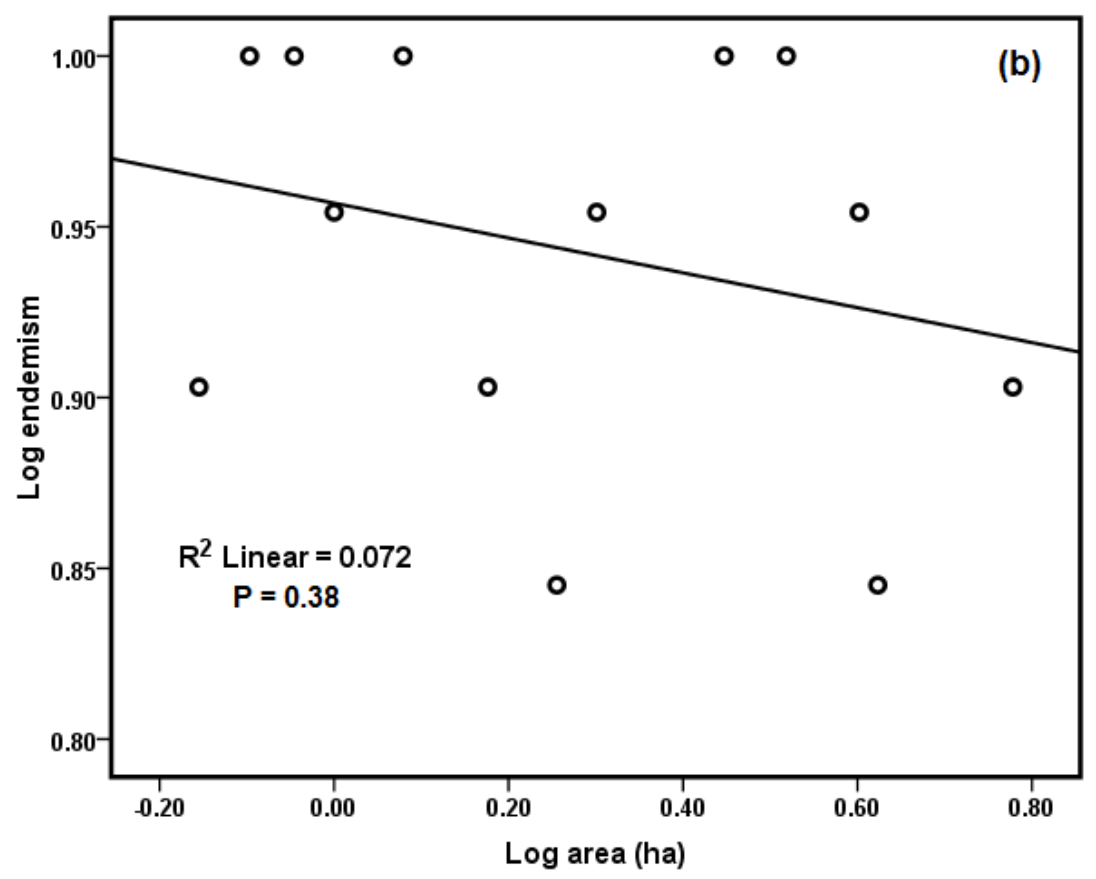

Figure 5b. The log endemism to (log) and swamp log area (ha) $(R 2=0.072, N=13$, n.s.) of the thirteen surveyed swamps (shown as dot points) from thirteen swamps of the Upper Nilgiris, 
Swampy areas and vegetation community were not significantly correlated with swamp area among the thirteen swamps (Table 2). In particularly, there is no significant positive correlation between swamp-area $(\log )$ and total species richness $(r=0.12 ; n=$ $13 ; \mathrm{P}=0.70)$ or area size relative to endemism $(\mathrm{r}=-0.29 ; \mathrm{n}=13 ; \mathrm{P}=0.33)$ respectively. There was a marginal significant negative correlation found between swamp edge and interior species $(\mathrm{r}=-0.51 ; \mathrm{n}=13 ; \mathrm{P}=0.07)$. However, no significant relationship was found between edge or interior species richness with swamp area (edge: $\mathrm{r}=0.30 ; \mathrm{n}=13 ; \mathrm{P}=0.32$; interior: $\mathrm{r}=-0.02 ; \mathrm{n}=13, \mathrm{P}=0.94$ ).

Table 2. Pearson (s) Correlation Coefficient was tested between vegetation parameter and swamp size (ha) among thirteen swamps in the Nilgiri Mountains.

\begin{tabular}{lllll}
\hline $\begin{array}{l}\text { VEGETATION } \\
\text { PARAMETER }\end{array}$ & $\begin{array}{l}\text { SWAMP } \\
\text { AREA }\end{array}$ & EDGE & ENDEMISM & SWAMP INTERIOR \\
\hline EDGE & $0.30^{\text {n.s }}$ & & & \\
P-VALUE & 0.32 & & & \\
ENDEMISM & $-0.29^{\text {n.s }}$ & $0.03^{\text {n.s }}$ & & \\
& 0.33 & 0.91 & & \\
SWAMP & & & & \\
INTERIOR & $-0.02^{\text {n.s }}$ & $-0.51^{\text {n.s }}$ & $0.40^{\text {n.s }}$ & \\
& 0.94 & 0.07 & 0.18 & \\
SPECIES & $0.12^{\text {n.s }}$ & $-0.12^{\text {n.s }}$ & $0.48^{\text {n.s }}$ & $0.91^{* *}$ \\
RICHNESS & 0.70 & 0.71 & 0.09 & 0.00 \\
\hline
\end{tabular}

**significant at $<0.0001 ; n . s=$ not significant

\section{Discussion}

\section{The effect of swamp area on species community and diversity}

Our findings suggest that swamp plant communities are not significantly influenced by area but are primarily controlled by the two habitat transition zones on their outer margins, predominantly shola and grasslands (Fig 6). This finding is contrary to our earlier study of shola forest species richness which significantly increased with increasing shola area (Mohandass and Davidar, 2010). However, among the shola forest, area significantly influences plant assemblages and vegetation features and in terms of local species richness, basal area and proportion of large trees, which all show positively relationships with area (Mohandass and Davidar, 2010). Swamp area and swamp size are determined and maintained by natural geological topography (physical environment) (Debski et al., 2000) including by various degrees of mountainous slopes which are integrated into aquatic habitat and edges (ecotonal boundaries). Furthermore, 
the relatively homogenous topographic environments within shola forests suggests that variation in eco-climatic factors has relatively little effect on species composition, due to the relative consistency within the regional conditions (Davidar et al., 2007; Mohandass and Davidar, 2009). However, species composition in swamps is influenced by annual rainfall, which couples in effects with steep mountainous slopes to create highly temporally variable conditions in terms of water influx. Former studies suggest that species richness in peat swamps is influenced by soil nutrients and rainfall (Sylvester Tan, 2004), our study indicates the same may be true within swamp environments. Swamp buffer areas also reflect physical environmental factors including topography, and drainage (soil properties), in addition to regional climatic factors (Fortin et al., 1997).
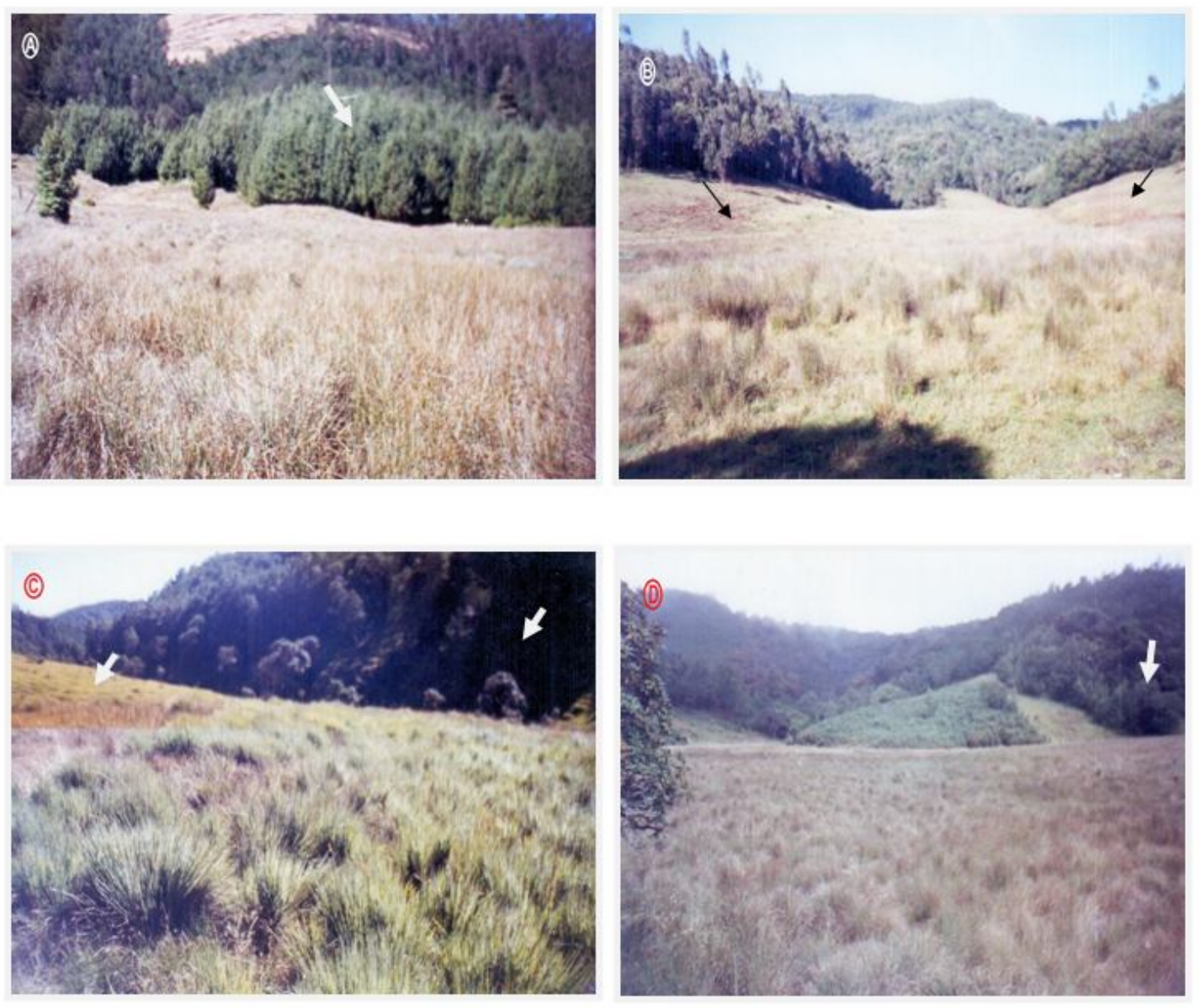

Figure 6 (A) Swamps surrounded by pine plantation at the edges (B) Swamps bounded by grassland communities along with lower slope edges $(C)$ One side of the swamp bounded by grassland and other side (arrow mark) bounded by sholas (native vegetation) (D)Swamps are

bounded and surrounded by different vegetation types grassland, sholas, and plantation.

\section{The relative diversity of the buffer zone}

The transition zone between swamps and surrounding vegetation types (i.e forests or grasslands) may have a higher biological diversity than either forest type which they mark the transition between, and therefore in themselves should be considered of high

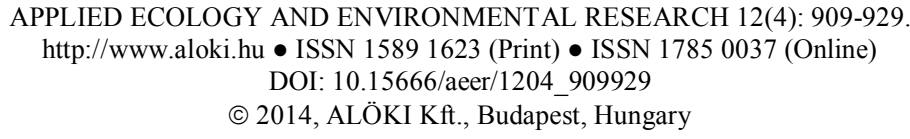


conservation importance (Leopold, 1933; Odum, 1983; Petts, 1990; Risser, 1995). In our study the composition of this transitory region includes both grassland and swamp species (Mohandass, 2008), however previous studies indicate that these transition regions may not facilitate the persistence of many species if frequently subject to intense disturbance (van der Maarel, 1990).

\section{Species distributions and community composition in swamps}

Communities and species abundance was found to change in the core (interior region) of the swamp, in addition to edge and buffer regions. In Swamp interior communities the majority of species are specialists for swamp environments. In the Nilgiris region the average species richness of 35.2 from the core regions of the swamp is significantly higher than in edge regions, with an average richness of 16.2 species. Given that species on swamp margins represent a subset of species found in interior regions of swamps, preventing further encroachment into swamps by grassland species may be a priority issue to maintain species which were only found in core regions of swamps.

A small proportion of species is shared across all swamps (15\%), but communities present vary between the interior and edge regions of the swamp. There are two dominant species common to multiple swamps across the Nilgiri region (Andropogon polyptychos and Eriochrysis rangacharii). However these species are found in different zones of the swamps, A. polyptychos is specialized in both edge and swamp interior, whereas $E$. rangacharii is specialized only swamp interior. Within the swamps, both Eriochrysis rangacharii and Coelachne perpusilla are endemic to swamp areas and endangered, due to their specialist habitat requirements, and the decreasing availability of swamp areas.

\section{Threats to swamp environments}

Within this study we also noticed a high presence of what we would consider grassland species within the swamp itself, and not only limited to the transition, or surrounding grassland. We suggest that grassland species present in such high levels within the swamp may reflect regular disturbance or may relate to natural succession, or the drying out of swamps and slow transition to grassland. Swamp disturbances may facilitate colonization by grassland species and increase the potential for these swamp environments to be replaced by grasslands into the future. Thus swamps habitat might be highly sensitive to disturbance, in addition to climate change, especially in climate parameters which reflect changes in seasonality of precipitation.

There is also strong evidence that exotic species may invade highly disturbed ecotones and cause these regions to gradually transition to other habitat types (Fox et al., 1997; Lloyd et al., 2000; Watkins et al., 2003). Study area locations where exotic tree species were introduced by the forest department (more than five decades ago) have become increasingly dry, and no longer support the original swamp community, many have transitioned or are transitioning to grassland. Plantations further impact the swamp community through increasing the local water deficit during the dry season thereby assisting new colonizers during drier periods of the year. The diversity of tree species in tropical rainforests in the Western Ghats decreases significantly with increasing length of dry season (Davidar et al., 2005). Therefore the length of dry season may influence 
the plant community and the recruitment of grassland species into areas which are currently occupied by swamps.

Within the Upper Nilgiris, sholas have increased in species richness and overall area through various deterministic processes (Mohandass and Davidar, 2010). Shola species have progressively spread into grasslands through edge expansion, natural colonization by seed dispersal, indicating that shola species have ability and capacity to germinate in the grasslands. But in swamps, edge effects refers to the effect of a prevailing boundary between contrasting spatial environments makes swamps vulnerable to invasion by surrounding ecotones, whilst being topographically limited and therefore unable to expand (Mesquita et al. 1999; Cronin 2003; Pohlman et al. 2007). Moreover, exotic tree plantations at the boundary threatening to swamp plant communities, because high water demands of plant communities on swamp boundaries cause soils to progressively dry and therefore encroachment of other species increases the potential for further invasions and progressive conversion of swamp areas into other habitat types. The vulnerability of individual swamps therefore depends on the topography and climate of the region, in addition to the degree of disturbance and modification to the area, as disturbance can act to exacerbate soil drying (and thereby transition to other habitat types) especially if the climate is also changing seasonal water availability.

\section{Summary}

Swamps of upper Nilgiris region represent fragile ecosystems and are the sole habitat for a number of endemic threatened species. The conservation of these fragile ecosystems presents a challenging task for conservationists, as enhanced restoration and rehabilitation of swamp habitat within the upper Nilgiris must occur in conjunction with sustainable management and development. In addition further experimental research is needed to understand the swamp community evolutionary processes especially through a detailed assessment on effect of ecotone and soil dynamics.

Acknowledgements. This publication was supported by National Natural Science Foundation of China (NSFC) through Young Scientist Grant. No. 31200173. P.R. China. We are thankful Dr. Qing-Jun Li for facilitate to writing this paper. We would like to thank Edhkwehlynawd Botanical Refuge (EBR) Centre Trust for funding this project. We thank Dr. Tarun Chhabra, and Mrs. Supriya Sahu (ex collector of Nilgiris), for giving us the opportunity to undertake this study. We thank Dr. Mahua Ghara who made valuable editorial comments for earlier version of the manuscript. We also thank Dr. Suresh Baburaj, Head of Survey of Medicinal Plants and Collection Unit, Ootacamund, for issuing equipment and floras. We thankful to Tamilnadu Forest Department for granting us permission to work in the Reserved Forests. Mr. D. Hegde, Director, Chamraj Group, for logistic support and keen interest in our efforts. Mr. M. Iqbal, and Mr. P. Dambekodi, successive Managers of the Korakundah Tea Estate, Chamraj Group, who have provided crucial help without which this study would have been impossible.

\section{REFERENCES}

[1] Ahmedullah, M., Nayar, M.P. (1986): Endemic plants of the Indian Region. - Series. IV. Vol. I. Peninsular India, Botanical Survey of India. Calcutta.

[2] Arrhenius, O. (1921) Species and area. - Journal of Ecology, 9, 95-99.

[3] Bor, N. L. (1960): The Grasses of Burma, Ceylon, India and Pakistan. - Pergamon Press, Oxford, London, New York, Paris.

[4] Bremer, B., K. Bremer, M.W. Chase, M. F. Fay, J. L. Reveal, D. E.Soltis, P. S. Soltis \& P. F. Stevens. 2009. An update of the Angiosperm Phylogeny Group classification for the

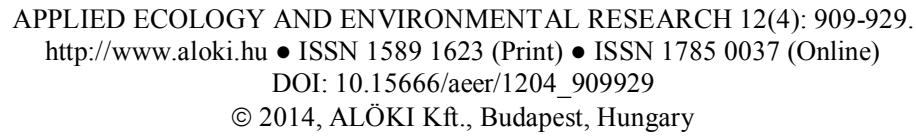


orders and families of flowering plants: APG III. - Botanical Journal of the Linnean Society 161: 105-121.

[5] Brooks, T.M., Hanah, L., da Fonseca, G.A.B., Mittermeier, R.A. (2001): Prioritizing hotspots, representing transitions. -Trends in Ecology and Evolution 16: 673.

[6] Davidar, P., Mohandass, D., Vijayan, L. 2007. Floristic inventory of woody plants in a tropical montane (shola) forest in the Palni hills of the Western Ghats, India. -Tropical Ecology 48: 15-25.

[7] Davidar, P., Puyravaud, J-P., Leigh, E.G.Jr. (2005): Changes in rain forest tree diversity, dominance and rarity across a seasonality gradient in the Western Ghats, India. -Journal of Biogeography 32: 493-501.

[8] Debski, I., Burslem, D. F. R. P., Lamb, D. (2000): Ecological processes maintaining differential tree species distributions in an Australian subtropical rain forest: implications for models of species coexistence.-Journal of Tropical Ecology 16: 387-415.

[9] Dong, X., Patton, B., Nyren, P., Limb, R., Chihacek, L., Kirby, D., Deckard, E. (2011): Leaf-water relations of a native and an introduced grass species in the mixed-grass prairie under cattle grazing. -Applied Ecology and Environmental Research 9: 311-331.

[10] Fortin, M.-J. (1997): Effects of data types on vegetation boundary delineation. -Canadian Journal of Forest Research 27: 1851-1858.

[11] Fox, B.J., Taylor, J. E., Fox, M.D., Williams, C. (1997): Vegetation changes across edges of rainforest remnants. -Biological Conservation 82: 1-13.

[12] Fyson, P.F. (1932): The Flora of the South Indian Hill Stations. - Government Press, Madras.

[13] Gamble, J.S. (1967): Flora of the Presidency of Madras. - Botanical Survey of India, Calcutta.

[14] Gleason, H.A. (1922) On the relation between species and area. - Ecology 3: 158-162.

[15] Gonzalez, M., Ladet, S., Deconchat, M., Cabanettes, A., Alard, D., Balent, G. (2010): Relative contribution of edge and interior zones to patch size effect on species richness: An example for woody plants. -Forest Ecology and Management 259: 266-274.

[16] Hammer, O., Harper, D. A. T., Ryan, P.D. (2001): PAST: Paleontological statistics software package for education and data analysis. -Palaeontologia Electronica $4: 9 \mathrm{pp}$.

[17] He, F., Hubbell, S.P. (2011): Species-area relationships always overestimate extinction rates from habitat loss. -Nature 473: 368-371.

[18] Holt, D.R.., Lawton, J.H., Polis, G.A., Martinez, N.D. (1999): Trophic Rank and the Species-area relationship. -Ecology 80: 1495-1504.

[19] Kent, M., Gill, W.J., Weaver, R.E., Armitage, R.P. (1997): Landscape and plant community boundaries in biogeography.-Progress in Physical Geography 21: 315-353.

[20] Leopold, A. 1933. Game management. -Charles Schribner's Sons. New York.

[21] Lloyd, K.M., Mcqueen, A.A.M., Lee, B.J., Wilson, R.C.B., Walker, S., Wilson, J.B. (2000): Evidence on ecotone concepts from switch, environmental and anthropogenic ecotones. -Journal of Vegetation Science 11: 903-910.

[22] Matthew, K.M. (1999): The Flora of the Palni Hills, South India. - Vol. I.The Rapinat Herbarium. Thiruchirapalli.

[23] Mohandass, D. (2008): Floristic Distribution in Montane Swamps of the Nilgiri Mountains, Southern India. - International Journal of Ecology and Environmental Sciences 34: 55-62.

[24] Mohandass, D., Davidar, P. (2009): Floristic structure and diversity of a tropical montane evergreen forest (shola) of the Nilgiri Mountains, southern India. -Tropical Ecology 50: 219-229.

[25] Mohandass, D., Davidar, P. (2010): The relationship between area, and vegetation structure and diversity in montane forest (shola) patches in southern India. - Plant Ecology \& Diversity 3: 67-76. 
[26] Mohandass, D., (2013): Pollination Ecology of Impatiens rufescens (Balsamineae) - An endemic annual herb from Nilgiri Mountains, Western Ghats, India. - International Journal of Ecology and Environmental Sciences 39: 59-65.

[27] Moody, A., (2000): Analysis of plant species diversity with respect to island characteristics on the Channel Islands, California. - Journal of Biogeography 27: 711723.

[28] Nair, N.C., Henry, A.N. (1983): Flora of Tamil Nadu. -Botanical Survey of India, Vol. III. Coimbatore. India.

[29] Nayar, M.P., Sastry, A.R.K. (1987): Red Data Book of Indian Plants. -Botanical Survey of India, Calcutta.

[30] Nirmal Kumar, J.I., Cinioommen, C. (2011): Phytoplankton composition in relation to hydrochemical properties of tropical community wetland, Kanewal, Gujarat, India. Applied Ecology and Environmental Research 9: 279-292.

[31] Odum, E.P. 1983. Basic ecology. -Saunders College Publishing, Philadelphia.

[32] Petts, G.E. (1990): The role of ecotones in aquatic landscape management. - In: The Ecology and management of aquatic-terrestrial ecotones (Ed. by R.J. Naiman and H. Décamps), pp. 227-261. UNESCO, Paris.

[33] Pitman, N.C.A., Andino, J.E.G., Aulestia, M., Cerón, C.E., Neill, D.A. Palacios, W., Rivas-Torees, G. Silman, M.R., Terborgh, J.W. (2014): Distribution and abundance of tree species in swamp forests of Amazonian Ecuador. -Ecography 37: 001-014.

[34] Puyravaud, J.P., Mohandass, D., Chhabra, T. (2003): A rediscovery of Eriochrysis rangacharii Fischer (Poaceae) in the Nilgiri Mountains of southern India. - Candollea 58: 97-100.

[35] Puyravuad, J.P., Mohandass, D., Davidar, P. (2012): .Impact of human-related disturbance on Eriochrysis rangacharii Fischer, a rare keystone endemic grass (Nilgiris, southern India): a preliminary assessment. -Tropical Ecology 53: 25-32.

[36] Risser, P.R. (1995): The Status of the science examining ccotones - A Dynamic aspect of landscape is the area of steep gradients between more homogeneous vegetation associations. -Bioscience 45: 318-325.

[37] Rogers, W.E., Hartnett, D.C. (2001): Temporal vegetation dynamics and recolonization mechanisms on different-sized soil disturbances in tall grass prairie. -American Journal of Botany 88: 1634-1642.

[38] Rosenzweig, M. L. (1997): Species diversity in space and time. -2nd edn. Cambridge University Press, Cambridge.

[39] Rydin, H., Borgegard, S. O. (1988): Plant species richness on islands over a century of primary succession: Lake Hjalmaren. -Ecology 69: 916-927.

[40] Rybicki, J., Hanski, I. (2013): Species-area relationships and extinctions caused by habitat loss and fragmentation. -Ecology Letters 16: 27-38.

[41] Schoener, A. Schoener, T.W. (1981): The dynamics of the species-area relation in marine fouling systems. 1. Biological correlates of changes in the species-area slope.-American Naturalist 118, 339-360.

[42] Smith, T.B., Kark, S., Schneider, C.J., Wayne, R.K., Moritz, C. (2001): Biodiversity hotspots and beyond: the need for conserving environmental transitions. - Trends in Ecology and Evolution16: 431.

[43] Sylvester Tan, K.S. (2004): Floristic and structure diversity of peat swamp forest in Maludam National Park. -Sarawak Malaysia, Forest Research Centre, Sarawak Forestry Corporation, Malaysia.

[44] van der Maarel, E. (1990): Ecotones and ecoclines are different. -Journal of Vegetation Science 1: 135-138.

[45] Watkins, R.Z., Chen, J.Q., Pickens, J., Brosofske, K.D. (2003): Effects of forest roads on understory plants in a managed hardwood landscape. -Conservation Biology 17: 411419. 
[46] Whittaker, R.J., Willis, K.J., Field, R. (2001): Scale and species richness: towards a general, hierarchical theory of species diversity. -Journal of Biogeography 28: 453-470.

[47] Williams, C.B. (1943): Area and the number of species. -Nature 152: 264-267.

[48] Wilcox, B. A. (1980): Species number, stability, and equilibrium status of reptile faunas on the California islands. - The California Islands: proceedings of a multidisciplinary symposium (ed. by D. M. Power), pp. 551-564. Santa Barbara Museum of Natural History, Santa Barbara.

Appendix 1. Complete species list surveyed from thirteen swamps includes, species names, family, life-form, habit, plant group, and total number of frequency recorded in which swamps found in the Upper Nilgiri mountains, India.

\begin{tabular}{|c|c|c|c|c|c|}
\hline Species names & Family & $\begin{array}{l}\text { Life } \\
\text { form }\end{array}$ & Plant groups & Habit & $\begin{array}{l}\text { Total } \\
\text { number } \\
\text { of } \\
\text { frequency }\end{array}$ \\
\hline $\begin{array}{l}\text { Ageratina adenophora } \\
\text { (Spreng.) R.M.King \& } \\
\text { H.Rob. }\end{array}$ & Compositae & Forb & Dicots & $\begin{array}{l}\text { Annual } \\
\text { forbs }\end{array}$ & 5 \\
\hline Anaphalis brevifolia DC. & Compositae & Forb & Dicots & $\begin{array}{l}\text { Annual } \\
\text { forbs }\end{array}$ & 13 \\
\hline $\begin{array}{l}\text { Andropogon lividus } \\
\text { Thwaites }\end{array}$ & Poaceae & Grass & Monocots & $\begin{array}{l}\text { Perrenial } \\
\text { grass }\end{array}$ & 10 \\
\hline $\begin{array}{l}\text { Andropogon polyptychos } \\
\text { Steud }\end{array}$ & Poaceae & Grass & Monocots & $\begin{array}{l}\text { Perrenial } \\
\text { grass }\end{array}$ & 12 \\
\hline $\begin{array}{l}\text { Anemone rivularis Buch.- } \\
\text { Ham. ex DC. }\end{array}$ & Ranunculaceae & Forb & Dicots & $\begin{array}{l}\text { Annual } \\
\text { forbs }\end{array}$ & 2 \\
\hline $\begin{array}{l}\text { Athyrium hohenackerianum } \\
\text { T. Moore }\end{array}$ & Athyriaceae & Forb & Pteridophytes & $\begin{array}{l}\text { Perennial } \\
\text { forbs }\end{array}$ & 3 \\
\hline $\begin{array}{l}\text { Bolboschoenus maritimus } \\
\text { (L.) Palla }\end{array}$ & Cyperaceae & Forb & Dicots & $\begin{array}{l}\text { Perennial } \\
\text { forbs }\end{array}$ & 4 \\
\hline $\begin{array}{l}\text { Bupleurum distichophyllum } \\
\text { Wight \& Arn. }\end{array}$ & Apiaceae & Forb & Dicots & $\begin{array}{l}\text { Annual } \\
\text { forbs }\end{array}$ & 3 \\
\hline Carex capillacea Boott & Cyperaceae & Forb & Monocots & $\begin{array}{l}\text { Perrenial } \\
\text { grass }\end{array}$ & 5 \\
\hline Carex lindleyana Nees & Cyperaceae & Forb & Monocots & $\begin{array}{l}\text { Perrenial } \\
\text { grass }\end{array}$ & 7 \\
\hline $\begin{array}{l}\text { Carex nubigena D.Don ex } \\
\text { Tilloch \& Taylor }\end{array}$ & Cyperaceae & Forb & Monocots & $\begin{array}{l}\text { Perrenial } \\
\text { grass }\end{array}$ & 4 \\
\hline Carex phacota Spreng. & Cyperaceae & Forb & Monocots & $\begin{array}{l}\text { Perrenial } \\
\text { grass }\end{array}$ & 6 \\
\hline Centella asiatica (L.) Urb. & Apiaceae & Forb & Dicots & $\begin{array}{l}\text { Perennial } \\
\text { forbs }\end{array}$ & 7 \\
\hline $\begin{array}{l}\text { Chrysopogon nodulibarbis } \\
\text { (Hochst. ex Steud.) } \\
\text { Henrard }\end{array}$ & Poaceae & Grass & Monocots & $\begin{array}{l}\text { Perrenial } \\
\text { grass }\end{array}$ & 9 \\
\hline $\begin{array}{l}\text { Cirsium abukumense } \\
\text { Kadota }\end{array}$ & Compositae & Forb & Dicots & $\begin{array}{l}\text { Annual } \\
\text { forbs }\end{array}$ & 8 \\
\hline $\begin{array}{l}\text { Coelachne perpusilla (Nees } \\
\text { ex Steud.) Thwaites }\end{array}$ & Poaceae & Grass & Monocots & $\begin{array}{l}\text { Perrenial } \\
\text { grass }\end{array}$ & 11 \\
\hline $\begin{array}{l}\text { Commelina clavata } \\
\text { C.B.Clarke }\end{array}$ & Commelinaceae & Forb & Monocots & $\begin{array}{l}\text { Annual } \\
\text { forbs }\end{array}$ & 7 \\
\hline Conyza bonariensis (L.) & Compositae & Forb & Dicots & $\begin{array}{l}\text { Annual } \\
\text { forbs }\end{array}$ & 2 \\
\hline Cyanotis obtusa (Trimen) & Commelinaceae & Forb & Monocots & Perrenial & 7 \\
\hline
\end{tabular}




\begin{tabular}{|c|c|c|c|c|}
\hline Trimen & & & & grass \\
\hline $\begin{array}{l}\text { Cyrtococcum deccanense } \\
\text { Bor }\end{array}$ & Poaceae & Grass & Monocots & $\begin{array}{l}\text { Annual } \\
\text { grass }\end{array}$ \\
\hline $\begin{array}{l}\text { Dichrocephala } \\
\text { chrysanthemifolia (Blume) } \\
\text { DC. }\end{array}$ & Compositae & Forb & Dicots & $\begin{array}{l}\text { Annual } \\
\text { forbs }\end{array}$ \\
\hline Digitaria stricta Roth & Poaceae & Grass & Monocots & $\begin{array}{l}\text { Annual } \\
\text { grass }\end{array}$ \\
\hline Drosera burmanni Vahl & Lentibularaceae & Forb & Dicots & $\begin{array}{l}\text { Annual } \\
\text { forbs }\end{array}$ \\
\hline Drosera peltata Thunb. & Lentibularaceae & Forb & Dicots & $\begin{array}{l}\text { Annual } \\
\text { forbs }\end{array}$ \\
\hline Eleocharis congesta D.Don & Cyperaceae & Forb & Dicots & $\begin{array}{l}\text { Perennial } \\
\text { forbs }\end{array}$ \\
\hline Erigeron karvinskianus DC & Compositae & Forb & Dicots & $\begin{array}{l}\text { Perennial } \\
\text { forbs }\end{array}$ \\
\hline $\begin{array}{l}\text { Eriocaulon brownianum } \\
\text { Mart. }\end{array}$ & Eriocaulaceae & Forb & Monocots & $\begin{array}{l}\text { Perrenial } \\
\text { grass }\end{array}$ \\
\hline $\begin{array}{l}\text { Eriocaulon odoratum } \\
\text { Dalzell }\end{array}$ & Eriocaulaceae & Forb & Monocots & $\begin{array}{l}\text { Perrenial } \\
\text { grass }\end{array}$ \\
\hline $\begin{array}{l}\text { Eriocaulon robustum } \\
\text { Steud. }\end{array}$ & Eriocaulaceae & Forb & Monocots & $\begin{array}{l}\text { Perrenial } \\
\text { grass }\end{array}$ \\
\hline $\begin{array}{l}\text { Eriochrysis rangacharii } \\
\text { C.E.C.Fisch. }\end{array}$ & Poaceae & Grass & Monocots & $\begin{array}{l}\text { Perrenial } \\
\text { grass }\end{array}$ \\
\hline $\begin{array}{l}\text { Eulalia phaeothrix (Hack.) } \\
\text { Kuntze }\end{array}$ & Poaceae & Grass & Monocots & $\begin{array}{l}\text { Perrenial } \\
\text { grass }\end{array}$ \\
\hline $\begin{array}{l}\text { Fimbristylis } \\
\text { quinquangularis (Vahl) } \\
\text { Kunth }\end{array}$ & Cyperaceae & Forb & Monocots & $\begin{array}{l}\text { Annual } \\
\text { forbs }\end{array}$ \\
\hline $\begin{array}{l}\text { Fragaria nilgerrensis } \\
\text { Schltdl. ex J.Gay }\end{array}$ & Rosaceae & Forb & Dicots & $\begin{array}{l}\text { Annual } \\
\text { forbs }\end{array}$ \\
\hline Fragaria vesca $L$. & Rosaceae & Forb & Dicots & $\begin{array}{l}\text { Annual } \\
\text { forbs }\end{array}$ \\
\hline $\begin{array}{l}\text { Gaultheria fragrantissima } \\
\text { Wall. }\end{array}$ & Ericaceae & Tree & Dicots & $\begin{array}{l}\text { Perennial } \\
\text { woody } \\
\text { plants }\end{array}$ \\
\hline $\begin{array}{l}\text { Gentiana pedicellata } \\
\text { (D.Don) Wall. }\end{array}$ & Gentianaceae & Forb & Dicots & $\begin{array}{l}\text { Perennial } \\
\text { forbs }\end{array}$ \\
\hline $\begin{array}{l}\text { Gentiana pedicellata } \\
\text { subsp. zeylanica (Griseb.) } \\
\text { Halda }\end{array}$ & Gentianaceae & Forb & Dicots & $\begin{array}{l}\text { Perennial } \\
\text { forbs }\end{array}$ \\
\hline $\begin{array}{l}\text { Gentiana quadrifaria } \\
\text { Blume }\end{array}$ & Geraniaceae & Forb & Dicots & $\begin{array}{l}\text { Annual } \\
\text { forbs }\end{array}$ \\
\hline $\begin{array}{l}\text { Hydrocotyle sibthorpioides } \\
\text { Lam. }\end{array}$ & Araliaceae & Forb & Dicots & $\begin{array}{l}\text { Annual } \\
\text { forbs }\end{array}$ \\
\hline $\begin{array}{l}\text { Hypochoeris argentina } \\
\text { Cabrera }\end{array}$ & Compositae & Forb & Dicots & $\begin{array}{l}\text { Annual } \\
\text { forbs }\end{array}$ \\
\hline Impatiens chinensis L. & Balsaminaceae & Forb & Dicots & $\begin{array}{l}\text { Annual } \\
\text { forbs }\end{array}$ \\
\hline Impatiens rufescens Benth. & Balsaminaceae & Forb & Dicots & $\begin{array}{l}\text { Annual } \\
\text { forbs }\end{array}$ \\
\hline $\begin{array}{l}\text { Isachne kunthiana (Wight } \\
\text { \& Arn. ex Steud.) Miq. }\end{array}$ & Poaceae & Grass & Monocots & $\begin{array}{l}\text { Perrenial } \\
\text { grass }\end{array}$ \\
\hline $\begin{array}{l}\text { Ischaemum commutatum } \\
\text { Hack. }\end{array}$ & Poaceae & Grass & Monocots & $\begin{array}{l}\text { Perrenial } \\
\text { grass }\end{array}$ \\
\hline Juncus effusus L. & Juncaceae & Forb & Monocots & $\begin{array}{l}\text { Perrenial } \\
\text { grass }\end{array}$ \\
\hline
\end{tabular}


Juncus inflexus L.

Juncus prismatocarpus

R.Br.

Kyllinga melanosperma

Nees

Laurembergia coccinea

Kanitz

Leucas marrubioides Desf.

Lipocarpha chinensis

(Osbeck) J.Kern

Neanotis indica (DC.)

W.H.Lewis

Ophelia corymbosa Griseb. Osbeckia brachystemon

Naudin

Osbeckia leschenaultiana

DC.

Oxalis corniculata L.

Oxalis spiralis Ruiz \& Pav. ex G.Don

Parnassia mysorensis F.

Heyne ex Wight \& Arn.

Pedicularis perrottetii

Benth.

Persicaria nepalensis

(Meisn.) Miyabe

Pimpinella leschenaultii

DC.

Pinalia polystachya

(A.Rich.) Kuntze

Pinus patula Schiede ex

Schltdl. \& Cham.

Plantago asiatica subsp. erosa (Wall.) Z.Yu Li

Pleiocraterium verticillare

(Wall. ex Wight \& Arn.)

Bremek.

Polytrias indica (Houtt.)

Veldkamp

Potentilla leschenaultiana

Ser.

Pteridium aquilinum (L.)

Kuhn

Pycreus flavidus (Retz.)

T.Koyama

Ranunculus diffusus DC.

Ranunculus reniformis

Wall. ex Wight \& Arn.

Rhododendron arboreum

Sm.

\begin{tabular}{|c|c|c|c|}
\hline Juncaceae & Forb & Monocots & $\begin{array}{l}\text { Perrenial } \\
\text { grass }\end{array}$ \\
\hline Juncaceae & Forb & Monocots & $\begin{array}{l}\text { Perrenial } \\
\text { grass }\end{array}$ \\
\hline Cyperaceae & Forb & Monocots & $\begin{array}{l}\text { Perrenial } \\
\text { grass }\end{array}$ \\
\hline Haloragaceae & Forb & Dicots & $\begin{array}{l}\text { Perennial } \\
\text { forbs }\end{array}$ \\
\hline Lamiaceae & Forb & Dicots & $\begin{array}{l}\text { Perennial } \\
\text { forbs }\end{array}$ \\
\hline Cyperaceae & Forb & Monocots & $\begin{array}{l}\text { Perrenial } \\
\text { grass }\end{array}$ \\
\hline Rubiaceae & Forb & Dicots & $\begin{array}{l}\text { Perennial } \\
\text { forbs }\end{array}$ \\
\hline Gentianaceae & Forb & Dicots & $\begin{array}{l}\text { Annual } \\
\text { forbs }\end{array}$ \\
\hline $\begin{array}{l}\text { Melastomatacea } \\
\text { e }\end{array}$ & Forb & Dicots & $\begin{array}{l}\text { Annual } \\
\text { forbs }\end{array}$ \\
\hline $\begin{array}{l}\text { Melastomatacea } \\
\mathrm{e}\end{array}$ & $\begin{array}{l}\text { Shru } \\
\mathrm{b}\end{array}$ & Dicots & $\begin{array}{l}\text { Perennial } \\
\text { woody } \\
\text { plants }\end{array}$ \\
\hline Oxalidaceae & Forb & Dicots & $\begin{array}{l}\text { Annual } \\
\text { forbs }\end{array}$ \\
\hline Oxalidaceae & Forb & Dicots & $\begin{array}{l}\text { Annual } \\
\text { forbs }\end{array}$ \\
\hline Celastraceae & Forb & Dicots & $\begin{array}{l}\text { Annual } \\
\text { forbs }\end{array}$ \\
\hline Orobanchaceae & Forb & Dicots & $\begin{array}{l}\text { Annual } \\
\text { forbs }\end{array}$ \\
\hline Polyagonaceae & Forb & Dicots & $\begin{array}{l}\text { Perennial } \\
\text { forbs }\end{array}$ \\
\hline Apiaceae & Forb & Dicots & $\begin{array}{l}\text { Perennial } \\
\text { forbs }\end{array}$ \\
\hline Orchidaceae & Forb & Monocots & $\begin{array}{l}\text { Annual } \\
\text { forbs }\end{array}$ \\
\hline Pinaceae & Tree & $\begin{array}{l}\text { Gymnosperm } \\
\mathrm{s}\end{array}$ & $\begin{array}{l}\text { Perennial } \\
\text { woody } \\
\text { plants }\end{array}$ \\
\hline Plantaginaceae & Forb & Dicots & $\begin{array}{l}\text { Perennial } \\
\text { forbs }\end{array}$ \\
\hline Rubiaceae & Forb & Dicots & $\begin{array}{l}\text { Perennial } \\
\text { forbs }\end{array}$ \\
\hline Poaceae & Grass & Monocots & $\begin{array}{l}\text { Perrenial } \\
\text { grass }\end{array}$ \\
\hline Rosaceae & Forb & Dicots & $\begin{array}{l}\text { Perennial } \\
\text { forbs }\end{array}$ \\
\hline Denstaedtiaceae & Forb & Pteridophytes & $\begin{array}{l}\text { Annual } \\
\text { forbs }\end{array}$ \\
\hline Cyperaceae & Forb & Monocots & $\begin{array}{l}\text { Perrenial } \\
\text { grass }\end{array}$ \\
\hline Ranunculaceae & Forb & Dicots & $\begin{array}{l}\text { Perennial } \\
\text { forbs }\end{array}$ \\
\hline Ranunculaceae & Forb & Dicots & $\begin{array}{l}\text { Perennial } \\
\text { forbs }\end{array}$ \\
\hline Ericaceae & Tree & Dicots & $\begin{array}{l}\text { Perennial } \\
\text { woody } \\
\text { plants }\end{array}$ \\
\hline
\end{tabular}




\begin{tabular}{|c|c|c|c|c|c|}
\hline $\begin{array}{l}\text { Rhynchospora rugosa } \\
\text { (Vahl) Gale }\end{array}$ & Cyperaceae & Forb & Monocots & $\begin{array}{l}\text { Perrenial } \\
\text { grass }\end{array}$ & 12 \\
\hline $\begin{array}{l}\text { Rotala fysonii Blatt. \& } \\
\text { Hallb. }\end{array}$ & Lythraceae & Forb & Dicots & $\begin{array}{l}\text { Annual } \\
\text { forbs }\end{array}$ & 11 \\
\hline Rubus racemosus Genev. & Rosaceae & $\begin{array}{l}\text { Shru } \\
\text { b }\end{array}$ & Dicots & $\begin{array}{l}\text { Perennial } \\
\text { woody } \\
\text { plants }\end{array}$ & 4 \\
\hline Satyrium nepalense D.Don & Orchidaceae & Forb & Monocots & $\begin{array}{l}\text { Annual } \\
\text { forbs }\end{array}$ & 8 \\
\hline $\begin{array}{l}\text { Senecio wightii (DC. ex } \\
\text { Wight) Benth. ex } \\
\text { C.B.Clarke }\end{array}$ & Compositae & Forb & Dicots & $\begin{array}{l}\text { Annual } \\
\text { forbs }\end{array}$ & 11 \\
\hline Swertia minor T.Cooke & Gentianaceae & Forb & Monocots & $\begin{array}{l}\text { Annual } \\
\text { forbs }\end{array}$ & 1 \\
\hline $\begin{array}{l}\text { Themeda tremula (Nees ex } \\
\text { Steud.) Hack. }\end{array}$ & Poaceae & Grass & Monocots & $\begin{array}{l}\text { Perrenial } \\
\text { grass }\end{array}$ & 5 \\
\hline $\begin{array}{l}\text { Utricularia graminifolia } \\
\text { Vahl }\end{array}$ & Lentibulariaceae & Forb & Dicots & $\begin{array}{l}\text { Annual } \\
\text { forbs }\end{array}$ & 11 \\
\hline Utricularia scandens Benj. & Lentibulariaceae & Forb & Dicots & $\begin{array}{l}\text { Annual } \\
\text { forbs }\end{array}$ & 3 \\
\hline Viola pilosa Blume & Violaceae & Forb & Dicots & $\begin{array}{l}\text { Perennial } \\
\text { forbs }\end{array}$ & 11 \\
\hline $\begin{array}{l}\text { Wahlenbergia marginata } \\
\text { (Thunb.) A.DC. }\end{array}$ & Campanulaceae & Forb & Dicots & $\begin{array}{l}\text { Perennial } \\
\text { forbs }\end{array}$ & 5 \\
\hline Xyris capensis Thunb. & Xyridaceae & Forb & Monocots & $\begin{array}{l}\text { Annual } \\
\text { forbs }\end{array}$ & 13 \\
\hline
\end{tabular}


Appendix 2. List of frequency of each species distributed in each swamp based on presence and absence qualitative assessment among thirteen swamps in the Korakundah and Upper Bhavani Reserve Forest, Nilgiri Mountains, southern India.

\begin{tabular}{|c|c|c|c|c|c|c|c|c|c|c|c|c|c|c|c|c|}
\hline Plant species & Family & $\begin{array}{l}\text { Life- } \\
\text { form }\end{array}$ & GD & KT & KG & KK & $\mathrm{KV}$ & NT & $\mathrm{NU}$ & OT & PT1 & PT2 & $\mathrm{PC}$ & QT & TE & $\begin{array}{l}\text { Grand } \\
\text { Total }\end{array}$ \\
\hline Ageratina adenophora (Spreng.) R.M.King \& H.Rob. & Compositae & Forb & 0 & 0 & 0 & 0 & 1 & 0 & 0 & 0 & 1 & 0 & 1 & 1 & 1 & 5 \\
\hline Anaphalis brevifolia DC. & Compositae & Forb & 1 & 1 & 1 & 1 & 1 & 1 & 1 & 1 & 1 & 1 & 1 & 1 & 1 & 13 \\
\hline Andropogon lividus Thwaites & Poaceae & Grass & 0 & 1 & 0 & 1 & 1 & 0 & 1 & 1 & 1 & 1 & 1 & 1 & 1 & 10 \\
\hline Andropogon polyptychos Steud & Poaceae & Grass & 1 & 1 & 1 & 1 & 1 & 1 & 1 & 1 & 1 & 1 & 1 & 1 & 0 & 12 \\
\hline Anemone rivularis Buch.-Ham. ex DC. & Ranunculaceae & Forb & 1 & 0 & 0 & 0 & 0 & 0 & 0 & 0 & 0 & 0 & 0 & 1 & 0 & 2 \\
\hline Athyrium hohenackerianum T. Moore & Athyriaceae & Forb & 0 & 0 & 0 & 0 & 1 & 0 & 0 & 1 & 0 & 0 & 0 & 1 & 0 & 3 \\
\hline Bolboschoenus maritimus (L.) Palla & Cyperaceae & Forb & 1 & 0 & 1 & 0 & 1 & 0 & 0 & 0 & 0 & 0 & 1 & 0 & 0 & 4 \\
\hline Bupleurum distichophyllum Wight \& Arn. & Apiaceae & Forb & 0 & 0 & 0 & 1 & 0 & 0 & 1 & 0 & 1 & 0 & 0 & 0 & 0 & 3 \\
\hline Carex capillacea Boott & Cyperaceae & Forb & 0 & 0 & 0 & 0 & 1 & 0 & 0 & 0 & 1 & 1 & 1 & 1 & 0 & 5 \\
\hline Carex lindleyana Nees & Cyperaceae & Forb & 1 & 1 & 1 & 0 & 0 & 0 & 0 & 1 & 0 & 1 & 1 & 1 & 0 & 7 \\
\hline Carex nubigena D.Don ex Tilloch \& Taylor & Cyperaceae & Forb & 1 & 0 & 0 & 1 & 0 & 0 & 0 & 1 & 0 & 0 & 0 & 1 & 0 & 4 \\
\hline Carex phacota Spreng. & Cyperaceae & Forb & 0 & 1 & 1 & 1 & 0 & 0 & 0 & 1 & 0 & 1 & 0 & 1 & 0 & 6 \\
\hline Centella asiatica (L.) Urb. & Apiaceae & Forb & 1 & 1 & 1 & 0 & 1 & 0 & 0 & 1 & 0 & 1 & 0 & 1 & 0 & 7 \\
\hline Chrysopogon nodulibarbis (Hochst. ex Steud.) Henrard & Poaceae & Grass & 0 & 0 & 0 & 1 & 1 & 1 & 1 & 1 & 0 & 1 & 1 & 1 & 1 & 9 \\
\hline Cirsium abukumense Kadota & Compositae & Forb & 1 & 0 & 0 & 0 & 1 & 0 & 1 & 1 & 0 & 1 & 1 & 1 & 1 & 8 \\
\hline Coelachne perpusilla (Nees ex Steud.) Thwaites & Poaceae & Grass & 1 & 1 & 0 & 1 & 1 & 1 & 1 & 1 & 1 & 1 & 0 & 1 & 1 & 11 \\
\hline Commelina clavata C.B.Clarke & Commelinaceae & Forb & 1 & 0 & 1 & 1 & 0 & 0 & 1 & 1 & 0 & 0 & 1 & 1 & 0 & 7 \\
\hline Conyza bonariensis (L.) & Compositae & Forb & 1 & 0 & 0 & 0 & 0 & 0 & 0 & 1 & 0 & 0 & 0 & 0 & 0 & 2 \\
\hline Cyanotis obtusa (Trimen) Trimen & Commelinaceae & Forb & 1 & 1 & 0 & 0 & 0 & 0 & 1 & 1 & 0 & 1 & 1 & 1 & 0 & 7 \\
\hline Cyrtococcum deccanense Bor & Poaceae & Grass & 1 & 1 & 1 & 1 & 1 & 1 & 1 & 1 & 1 & 1 & 1 & 1 & 1 & 13 \\
\hline Dichrocephala chrysanthemifolia (Blume) DC. & Compositae & Forb & 0 & 1 & 0 & 0 & 1 & 1 & 1 & 1 & 1 & 1 & 1 & 1 & 0 & 9 \\
\hline Digitaria stricta Roth & Poaceae & Grass & 1 & 1 & 1 & 1 & 1 & 1 & 1 & 1 & 1 & 1 & 1 & 1 & 1 & 13 \\
\hline Drosera burmanni Vahl & Lentibularaceae & Forb & 0 & 1 & 1 & 1 & 1 & 1 & 1 & 1 & 1 & 1 & 1 & 1 & 1 & 12 \\
\hline Drosera peltata Thunb. & Lentibularaceae & Forb & 0 & 0 & 0 & 1 & 0 & 0 & 0 & 0 & 1 & 0 & 0 & 0 & 1 & 3 \\
\hline Eleocharis congesta D.Don & Cyperaceae & Forb & 0 & 1 & 0 & 1 & 0 & 0 & 0 & 0 & 0 & 1 & 1 & 0 & 0 & 4 \\
\hline Erigeron karvinskianus DC & Compositae & Forb & 1 & 0 & 1 & 1 & 1 & 0 & 1 & 1 & 1 & 1 & 1 & 1 & 0 & 10 \\
\hline Eriocaulon brownianum Mart. & Eriocaulaceae & Forb & 1 & 1 & 1 & 1 & 1 & 1 & 1 & 1 & 1 & 1 & 1 & 1 & 1 & 13 \\
\hline Eriocaulon odoratum Dalzell & Eriocaulaceae & Forb & 1 & 1 & 1 & 1 & 1 & 0 & 1 & 1 & 1 & 0 & 1 & 1 & 1 & 11 \\
\hline Eriocaulon robustum Steud. & Eriocaulaceae & Forb & 1 & 0 & 1 & 0 & 1 & 1 & 1 & 1 & 1 & 1 & 1 & 1 & 1 & 11 \\
\hline Eriochrysis rangacharii C.E.C.Fisch. & Poaceae & Grass & 1 & 1 & 1 & 1 & 1 & 1 & 1 & 1 & 1 & 1 & 1 & 1 & 1 & 13 \\
\hline Eulalia phaeothrix (Hack.) Kuntze & Poaceae & Grass & 0 & 0 & 1 & 0 & 1 & 1 & 1 & 1 & 0 & 1 & 1 & 1 & 1 & 9 \\
\hline Fimbristylis quinquangularis (Vahl) Kunth & Cyperaceae & Forb & 0 & 0 & 0 & 0 & 0 & 0 & 0 & 1 & 0 & 0 & 0 & 0 & 0 & 1 \\
\hline Fragaria nilgerrensis Schltdl. ex J.Gay & Rosaceae & Forb & 1 & 1 & 0 & 1 & 0 & 1 & 1 & 1 & 1 & 1 & 1 & 1 & 1 & 11 \\
\hline Fragaria vesca $L$. & Rosaceae & Forb & 0 & 1 & 0 & 0 & 1 & 1 & 1 & 1 & 1 & 1 & 0 & 1 & 1 & 9 \\
\hline Gaultheria fragrantissima Wall. & Ericaceae & Tree & 0 & 0 & 1 & 1 & 1 & 0 & 0 & 0 & 0 & 0 & 0 & 0 & 1 & 4 \\
\hline Gentiana pedicellata (D.Don) Wall. & Gentianaceae & Forb & 1 & 1 & 1 & 1 & 1 & 1 & 1 & 1 & 1 & 1 & 1 & 1 & 1 & 13 \\
\hline Gentiana pedicellata subsp. zeylanica (Griseb.) Halda & Gentianaceae & Forb & 1 & 1 & 1 & 0 & 1 & 1 & 1 & 1 & 1 & 1 & 1 & 1 & 1 & 12 \\
\hline Gentiana quadrifaria Blume & Geraniaceae & Forb & 0 & 1 & 1 & 1 & 0 & 1 & 1 & 1 & 1 & 1 & 1 & 1 & 1 & 11 \\
\hline Hydrocotyle sibthorpioides Lam. & Araliaceae & Forb & 1 & 1 & 1 & 0 & 1 & 1 & 1 & 1 & 1 & 1 & 1 & 1 & 1 & 12 \\
\hline Hypochoeris argentina Cabrera & Compositae & Forb & 1 & 1 & 1 & 1 & 1 & 1 & 1 & 1 & 1 & 1 & 1 & 1 & 1 & 13 \\
\hline Impatiens chinensis $\mathrm{L}$. & Balsaminaceae & Forb & 0 & 0 & 1 & 0 & 1 & 0 & 1 & 0 & 0 & 1 & 0 & 1 & 0 & 5 \\
\hline Impatiens rufescens Benth. & Balsaminaceae & Forb & 1 & 1 & 1 & 1 & 1 & 1 & 1 & 1 & 1 & 1 & 1 & 1 & 1 & 13 \\
\hline Isachne kunthiana (Wight \& Arn. ex Steud.) Miq. & Poaceae & Grass & 1 & 1 & 1 & 1 & 1 & 1 & 1 & 1 & 1 & 1 & 1 & 1 & 1 & 13 \\
\hline Ischaemum commutatum Hack. & Poaceae & Grass & 1 & 1 & 1 & 1 & 0 & 0 & 1 & 1 & 1 & 1 & 1 & 1 & 0 & 10 \\
\hline Juncus effusus $\mathrm{L}$. & Juncaceae & Forb & 1 & 1 & 1 & 1 & 0 & 1 & 1 & 1 & 1 & 1 & 1 & 1 & 1 & 12 \\
\hline Juncus inflexus $\mathrm{L}$. & Juncaceae & Forb & 1 & 1 & 1 & 1 & 0 & 1 & 1 & 1 & 1 & 1 & 1 & 1 & 1 & 12 \\
\hline Juncus prismatocarpus R.Br. & Juncaceae & Forb & 1 & 1 & 1 & 1 & 1 & 1 & 1 & 1 & 1 & 1 & 1 & 1 & 1 & 13 \\
\hline Kyllinga melanosperma Nees & Cyperaceae & Forb & 1 & 0 & 1 & 0 & 0 & 0 & 1 & 1 & 1 & 1 & 0 & 1 & 0 & 7 \\
\hline Laurembergia coccinea Kanitz & Haloragaceae & Forb & 0 & 0 & 0 & 0 & 0 & 0 & 0 & 0 & 0 & 1 & 0 & 0 & 0 & 1 \\
\hline Leucas marrubioides Desf. & Lamiaceae & Forb & 1 & 1 & 1 & 1 & 1 & 1 & 0 & 1 & 1 & 1 & 1 & 1 & 1 & 12 \\
\hline Lipocarpha chinensis (Osbeck) J.Kern & Cyperaceae & Forb & 0 & 1 & 1 & 1 & 1 & 1 & 0 & 1 & 1 & 1 & 0 & 1 & 0 & 9 \\
\hline Neanotis indica (DC.) W.H.Lewis & Rubiaceae & Forb & 1 & 1 & 1 & 1 & 1 & 1 & 1 & 1 & 1 & 1 & 1 & 1 & 1 & 13 \\
\hline
\end{tabular}


Ophelia corymbosa Griseb.

Osbeckia brachystemon Naudin

Osbeckia leschenaultiana DC.

Oxalis corniculata L.

Oxalis spiralis Ruiz \& Pav. ex G.Don

Parnassia mysorensis F. Heyne ex Wight \& Arn.

Pedicularis perrotteti i Benth.

Persicaria nepalensis (Meisn.) Miyabe

Pimpinella leschenaultii DC.

Pinalia polystachya (A.Rich.) Kuntze

Pinus patula Schiede ex Schltdl. \& Cham.

Plantago asiatica subsp. erosa (Wall.) Z.Yu Li

Pleiocraterium verticillare (Wall. ex Wight \& Arn.) Bremek.

Polytrias indica (Houtt.) Veldkamp

Potentilla leschenaultiana Ser.

Pteridium aquilinum (L.) Kuhn

Pycreus flavidus (Retz.) T.Koyama

Ranunculus diffusus DC.

Ranunculus reniformis Wall. ex Wight \& Arn.

Rhododendron arboreum $\mathrm{Sm}$

Rhynchospora rugosa (Vahl) Gale

Rotala fysonii Blatt. \& Hallb.

Rubus racemosus Genev.

Satyrium nepalense D.Don

Senecio wightii (DC. ex Wight) Benth. ex C.B.Clarke

Swertia minor T.Cooke

Themeda tremula (Nees ex Steud.) Hack.

Utricularia graminifolia Vahl

Utricularia scandens Benj.

Viola pilosa Blume

Wahlenbergia marginata (Thunb.) A.DC.

Xyris capensis Thunb.

Grand Total

\begin{tabular}{|c|c|c|c|c|c|c|c|c|c|c|c|c|c|c|c|}
\hline Gentianaceae & Forb & 0 & 1 & 0 & 1 & 0 & 1 & 0 & 0 & 1 & 0 & 0 & 0 & 0 & 4 \\
\hline Melastomataceae & Forb & 1 & 1 & 1 & 1 & 1 & 1 & 1 & 1 & 1 & 1 & 1 & 1 & 1 & 13 \\
\hline Melastomataceae & Shrub & 0 & 1 & 0 & 0 & 0 & 0 & 0 & 0 & 1 & 1 & 1 & 0 & 0 & 4 \\
\hline Oxalidaceae & Forb & 1 & 1 & 1 & 1 & 1 & 1 & 1 & 1 & 1 & 1 & 1 & 1 & 0 & 12 \\
\hline Oxalidaceae & Forb & 0 & 1 & 0 & 0 & 0 & 0 & 0 & 1 & 0 & 0 & 0 & 1 & 0 & 3 \\
\hline Celastraceae & Forb & 0 & 1 & 0 & 1 & 0 & 1 & 1 & 1 & 1 & 1 & 1 & 1 & 1 & 10 \\
\hline Orobanchaceae & Forb & 1 & 0 & 0 & 0 & 0 & 0 & 0 & 0 & 10 & 0 & 0 & 0 & 0 & 1 \\
\hline Polyagonaceae & Forb & 0 & 1 & 1 & 1 & 1 & 1 & 1 & 1 & 1 & 0 & 1 & 1 & 0 & 10 \\
\hline Apiaceae & Forb & 1 & 1 & 0 & 0 & 0 & 1 & 0 & 0 & 1 & 0 & 0 & 0 & 0 & 4 \\
\hline Orchidaceae & Forb & 0 & 0 & 0 & 0 & 0 & 0 & 0 & 1 & 0 & 0 & 0 & 0 & 0 & 1 \\
\hline Pinaceae & Tree & 0 & 0 & 0 & 1 & 0 & 1 & 0 & 0 & $l_{0}$ & 0 & 0 & 0 & 0 & 2 \\
\hline Plantaginaceae & Forb & 1 & 1 & 1 & 1 & 0 & 1 & 1 & 1 & 1 & 1 & 0 & 1 & 1 & 11 \\
\hline Rubiaceae & Forb & 1 & 0 & 0 & 1 & 1 & 1 & 1 & 1 & 0 & 0 & 0 & 1 & 1 & 8 \\
\hline Poaceae & Grass & 1 & 1 & 0 & 1 & 0 & 1 & 1 & 1 & 1 & 1 & 0 & 1 & 1 & 10 \\
\hline Rosaceae & Forb & 1 & 1 & 0 & 1 & 1 & 1 & 1 & 1 & 1 & 1 & 1 & 1 & 1 & 12 \\
\hline Denstaedtiaceae & Forb & 0 & 1 & 1 & 0 & 0 & 1 & 1 & 1 & 1 & 1 & 0 & 0 & 0 & 7 \\
\hline Cyperaceae & Forb & 1 & 1 & 1 & 1 & 1 & 1 & 1 & 1 & $l_{1}$ & 1 & 1 & 1 & 0 & 12 \\
\hline Ranunculaceae & Forb & 0 & 0 & 0 & 1 & 1 & 0 & 0 & 1 & 0 & 0 & 0 & 0 & 0 & 3 \\
\hline Ranunculaceae & Forb & 1 & 1 & 1 & 1 & 1 & 1 & 1 & 1 & 1 & 1 & 1 & 1 & 1 & 13 \\
\hline Ericaceae & Tree & 0 & 0 & 1 & 1 & 1 & 1 & 0 & 0 & 0 & 0 & 0 & 1 & 1 & 6 \\
\hline Cyperaceae & Forb & 0 & 1 & 1 & 1 & 1 & 1 & 1 & 1 & 1 & 1 & 1 & 1 & 1 & 12 \\
\hline Lythraceae & Forb & 0 & 0 & 1 & 1 & 1 & 1 & 1 & 1 & 1 & 1 & 1 & 1 & 1 & 11 \\
\hline Rosaceae & Shrub & 0 & 1 & 0 & 0 & 0 & 1 & 1 & 0 & 1 & 0 & 0 & 0 & 0 & 4 \\
\hline Orchidaceae & Forb & 1 & 0 & 0 & 1 & 1 & 0 & 1 & 0 & 1 & 0 & 1 & 1 & 1 & 8 \\
\hline Compositae & Forb & 1 & 0 & 1 & 0 & 1 & 1 & 1 & 1 & 1 & 1 & 1 & 1 & 1 & 11 \\
\hline Gentianaceae & Forb & 1 & 0 & 0 & 0 & 0 & 0 & 0 & 0 & 0 & 0 & 0 & 0 & 0 & 1 \\
\hline Poaceae & Grass & 0 & 0 & 0 & 0 & 1 & 1 & 0 & 0 & 1 & 0 & 1 & 1 & 0 & 5 \\
\hline Lentibulariaceae & Forb & 1 & 1 & 1 & 1 & 1 & 1 & 0 & 1 & 1 & 1 & 0 & 1 & 1 & 11 \\
\hline Lentibulariaceae & Forb & 1 & 0 & 0 & 1 & 1 & 0 & 0 & 0 & 0 & 0 & 0 & 1 & 0 & 4 \\
\hline Violaceae & Forb & 1 & 1 & 1 & 1 & 1 & 1 & 1 & 1 & 1 & 1 & 0 & 1 & 1 & 12 \\
\hline Campanulaceae & Forb & 0 & 0 & 0 & 0 & 0 & 0 & 0 & 1 & 1 & 0 & 1 & 1 & 1 & 5 \\
\hline \multirow[t]{2}{*}{ Xyridaceae } & Forb & 1 & 1 & 1 & 1 & 1 & 1 & 1 & 1 & 1 & 1 & 1 & 1 & 1 & 13 \\
\hline & & 50 & 51 & 47 & 53 & 52 & 50 & 53 & 63 & 57 & 56 & 51 & 66 & 46 & \\
\hline
\end{tabular}

